\title{
Assimilation of lidar signals: application to aerosol forecasting in the western Mediterranean basin
}

Y. Wang ${ }^{1,2, *}$, K. N. Sartelet ${ }^{1}$, M. Bocquet ${ }^{1,3}$, P. Chazette ${ }^{2}$, M. Sicard ${ }^{4,5}$, G. D'Amico ${ }^{6}$, J. F. Léon ${ }^{7}$,

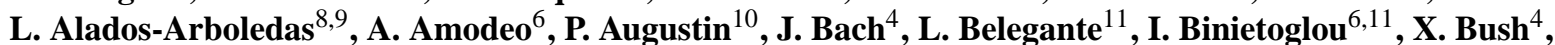
A. Comerón ${ }^{4}$, H. Delbarre ${ }^{10}$, D. García-Vízcaino ${ }^{4}$, J. L. Guerrero-Rascado ${ }^{8,9}$, M. Hervo ${ }^{12}$, M. Iarlorii $^{13}$, P. Kokkalis ${ }^{14}$, D. Lange ${ }^{4,5}$, F. Molero ${ }^{15}$, N. Montoux ${ }^{12}$, A. Muñoz ${ }^{4}$ C. Muñoz ${ }^{4}$, D. Nicolae ${ }^{11}$, A. Papayannis ${ }^{14}$, G. Pappalardo ${ }^{6}$, J. Preissler ${ }^{16, * *}$, V. Rizi ${ }^{13}$, F. Rocadenbosch ${ }^{4,5}$, K. Sellegri ${ }^{12}$, F. Wagner ${ }^{16, * *}$, and F. Dulac ${ }^{2}$

${ }^{1}$ CEREA, joint laboratory École des Ponts ParisTech - EDF R\&D, Université Paris-Est, 77455 Champs-sur-Marne, France

${ }^{2}$ LSCE, joint laboratory CEA-CNRS-UVSQ, UMR8212, 91191 Gif-sur-Yvette, France

${ }^{3}$ INRIA, Paris-Rocquencourt Research Center, Le Chesnay, France

${ }^{4}$ Remote Sensing Laboratory, Universitat Politècnica de Catalunya, Barcelona, Spain

${ }^{5}$ Centre de Recerca de l'Aeronàutica i de l'Espai - Institut d'Estudis Espacials de Catalunya,

Universitat Politècnica de Catalunya, Barcelona, Spain

${ }^{6}$ Consiglio Nazionale delle Ricerche-Istituto di Metodologie per l'Analisi Ambientale (CNR-IMAA),

Tito (Potenza), 85050, Italy

${ }^{7}$ Laboratoire d'Aérologie, Université Toulouse III, Centre national de la recherche scientifique, Toulouse, France

${ }^{8}$ IISTA, University of Granada, Autonomous Government of Andalusia, Av. del Mediterráneo s/n, 18006,

Granada, Spain

${ }^{9}$ Dpt. Applied Physics, University of Granada, Fuentenueva s/n, 18071, Granada, Spain

${ }^{10}$ LPCA, Université du Littoral Côte d'Opale, 59140 Dunkerque, France

${ }^{11}$ National Institute of R\&D for Optoelectronics, 409 Atomistilor Str. 77125, Magurele, Ilfov, Romania

${ }^{12}$ LaMP-CNRS, Observatoire de Physique de Globe, Clermont-Ferrand, France

${ }^{13}$ CETEMPS, Dipartimento di Scienze Fisiche e Chimiche, Università Degli Studi, L'Aquila, Italy

${ }^{14}$ NTUA, Physics Department, Laser Remote Sensing Laboratory, 15780 Zografou, Greece

${ }^{15}$ CIEMAT, Department of Environment, 28040 Madrid, Spain

${ }^{16}$ Geophysics Center of Evora, University of Evora, Rua Romao Ramalho 59, 7000 Evora, Portugal

*now at: Nansen Environmental and Remote Sensing Center, N-5006 Bergen, Norway

** now at: Centre for Climate and Air Pollution Studies, National University of Ireland

${ }^{* * * *}$ now at: Deutscher Wetterdienst, Hohenpeißenberg Meteorological Observatory,

Albin-Schwaiger-Weg 10, 82383 Hohenpeißenberg, Germany

Correspondence to: Y. Wang (wangy@cerea.enpc.fr)

Received: 18 March 2014 - Published in Atmos. Chem. Phys. Discuss.: 21 May 2014

Revised: 26 September 2014 - Accepted: 27 September 2014 - Published: 17 November 2014

Abstract. This paper presents a new application of assimilating lidar signals to aerosol forecasting. It aims at investigating the impact of a ground-based lidar network on the analysis and short-term forecasts of aerosols through a case study in the Mediterranean basin. To do so, we employ a data assimilation (DA) algorithm based on the optimal interpolation method developed in the POLAIR3D chem- istry transport model (CTM) of the POLYPHEMUS air quality modelling platform. We assimilate hourly averaged normalised range-corrected lidar signals $\left(\mathrm{PR}^{2}\right)$ retrieved from a $72 \mathrm{~h}$ period of intensive and continuous measurements performed in July 2012 by ground-based lidar systems of the European Aerosol Research Lidar Network (EARLINET) integrated into the Aerosols, Clouds, and Trace 
gases Research InfraStructure (ACTRIS) network and an additional system in Corsica deployed in the framework of the pre-ChArMEx (Chemistry-Aerosol Mediterranean Experiment)/TRAQA (TRAnsport à longue distance et Qualité de l'Air) campaign. This lidar campaign was dedicated to demonstrating the potential operationality of a research network like EARLINET and the potential usefulness of assimilation of lidar signals to aerosol forecasts. Particles with an aerodynamic diameter lower than $2.5 \mu \mathrm{m}\left(\mathrm{PM}_{2.5}\right)$ and those with an aerodynamic diameter higher than $2.5 \mu \mathrm{m}$ but lower than $10 \mu \mathrm{m}\left(\mathrm{PM}_{10-2.5}\right)$ are analysed separately using the lidar observations at each DA step. First, we study the spatial and temporal influences of the assimilation of lidar signals on aerosol forecasting. We conduct sensitivity studies on algorithmic parameters, e.g. the horizontal correlation length $\left(L_{\mathrm{h}}\right)$ used in the background error covariance matrix $(50 \mathrm{~km}$, $100 \mathrm{~km}$ or $200 \mathrm{~km}$ ), the altitudes at which DA is performed $(0.75-3.5 \mathrm{~km}, 1.0-3.5 \mathrm{~km}$ or $1.5-3.5 \mathrm{~km}$ a.g.1.) and the assimilation period length $(12 \mathrm{~h}$ or $24 \mathrm{~h})$. We find that DA with $L_{\mathrm{h}}=100 \mathrm{~km}$ and assimilation from 1.0 to $3.5 \mathrm{~km}$ a.g.l. during a $12 \mathrm{~h}$ assimilation period length leads to the best scores for $\mathrm{PM}_{10}$ and $\mathrm{PM}_{2.5}$ during the forecast period with reference to available measurements from surface networks. Secondly, the aerosol simulation results without and with lidar DA using the optimal parameters $\left(L_{\mathrm{h}}=100 \mathrm{~km}\right.$, an assimilation altitude range from 1.0 to $3.5 \mathrm{~km}$ a.g.l. and a $12 \mathrm{~h}$ DA period) are evaluated using the level 2.0 (cloud-screened and quality-assured) aerosol optical depth (AOD) data from AERONET, and mass concentration measurements $\left(\mathrm{PM}_{10}\right.$ or $\mathrm{PM}_{2.5}$ ) from the French air quality (BDQA) network and the EMEP-Spain/Portugal network. The results show that the simulation with DA leads to better scores than the one without DA for $\mathrm{PM}_{2.5}, \mathrm{PM}_{10}$ and AOD. Additionally, the comparison of model results to evaluation data indicates that the temporal impact of assimilating lidar signals is longer than $36 \mathrm{~h}$ after the assimilation period.

\section{Introduction}

Aerosols consist of tiny pieces of solid or liquid matter suspended in the atmosphere. They have an impact on vegetation and human health by penetrating the respiratory system, and can lead to respiratory and cardiovascular diseases (Dockery and Pope, 1996; Lauwerys et al., 2007). They also influence visibility (Wang et al., 2009) and affect the earth's environment and climate by changing the amount of incoming solar radiation and outgoing terrestrial long-wave radiation retained in the earth's system (Intergovernment Panel on Climate Control, IPCC, 2013). Furthermore, they have an indirect effect, by changing the microphysical properties of clouds (Intergovernment Panel on Climate Control, IPCC, 2013).
In order to model the transport and formation of aerosols, a variety of chemistry transport models (CTMs) have been developed (Simpson et al., 2003; Schaap et al., 2004; Hodzic et al., 2006; Sartelet et al., 2007). In air quality modelling, CTMs are often employed to forecast aerosol concentrations. For instance, the monitoring atmospheric composition and climate (MACC, http://www.gmes-atmosphere.eu/) model and the POLYPHEMUS air quality modelling system (http:// cerea.enpc.fr/en/prevision.html) perform real-time forecasts of aerosols over Europe. However, a CTM is always a simplification of the real atmosphere, and there are large uncertainties in aerosol modelling (Roustan et al., 2010). A CTM is limited in terms of spatial and temporal resolutions. It is also limited to a restricted selection of physical and chemical processes, which are often simplified or parametrised. In addition, input data are often highly uncertain. Initial and boundary conditions of pollutants are two crucial factors in forecasting. Since initial and boundary conditions are often outputs from a larger-scale simulation, or from a fixed set of climatological average values based on long-term observations, they usually lack accuracy. On the other hand, aerosol measurements provide detailed insights into the atmosphere's current state, using satellite observations on a global scale or in situ measurements from ground-based or airborne instruments. Unfortunately, although measurements can help to improve the knowledge of the atmosphere, they do not directly provide the necessary initial or boundary conditions for aerosol modelling.

A technique referred to as data assimilation (DA hereafter) was introduced to couple models and observations, and to improve the accuracy of input data of model forecasts, such as initial conditions or boundary conditions (Talagrand, 1997; Roustan and Bocquet, 2006). In meteorology, DA has been employed to improve forecasts for more than three decades (Lorenc, 1986; Kalnay, 2003; Lahoz et al., 2010). Common DA methods are the optimal interpolation (OI)/3dimensional variational (3D-Var) method (Daley, 1991), the ensemble Kalman filter (EnKF) (Evensen, 2009) and the 4dimensional variational (4D-Var) method (Le Dimet and Talagrand, 1986). Following efforts in DA for trace gas modelling (Austin, 1992; Fisher and Lary, 1995; Elbern and Schmidt, 1999), in recent years, DA has been increasingly applied to aerosol forecasts (Collins et al., 2001; Benedetti et al., 2009; Tombette et al., 2009; Pagowski et al., 2010; Li et al., 2013; Wang et al., 2013).

The OI method was used in several studies for improving initial conditions of CTMs. For example, it was first developed to assimilate AOD (aerosol optical depth) retrieved by satellite during the Indian Ocean Experiment (INDOEX) (Collins et al., 2001). The OI method was also used in a simplified radiative transfer model by Huneeus and Boucher (2007) to assimilate synthetic observations of MODIS (Moderate Resolution Imaging Spectroradiometer) and CALIPSO (Cloud-Aerosol Lidar with Orthogonal Polarization). Adhikary et al. (2008) assimilated monthly mean AOD data 
from MODIS and AERONET using the OI method to produce three-dimensional distributions of AOD over Asia. Niu et al. (2008) improved dust storm forecasts (dust concentrations) over China by assimilating satellite retrieval data and surface meteorological station data. Tombette et al. (2009) used the OI method over western Europe for assimilating $\mathrm{PM}_{10}$ (particulate matter with an aerodynamic diameter lower than $10 \mu \mathrm{m}$ ) mass concentration observations from the BDQA (Base de Données de la Qualité de l'Air) network. The OI method was also employed in a study of inverse modelling of optical observations (lidar backscatter coefficients and AOD) by chemical DA (Kahnert, 2009). Pagowski et al. (2010) used the OI over the United States of America for DA of $\mathrm{PM}_{2.5}$ (particulate matter of an aerodynamic diameter lower than $2.5 \mu \mathrm{m}$ ) observations. Liu et al. (2011) developed a DA system using the OI method within the National Centers for Environmental Prediction (NCEP) for assimilating MODIS AOD retrieval products (at $550 \mathrm{~nm}$ wavelength) from both the Terra and Aqua satellites and for analysing aerosol mass concentrations. Huneeus et al. (2012) used the OI method to estimate the emission fluxes of a range of aerosol species at a global scale by assimilating daily total and fine-mode AOD at $550 \mathrm{~nm}$ from MODIS into a global aerosol model of intermediate complexity. The OI method was used by Schwartz et al. (2012) individually or simultaneously to assimilate AOD at $550 \mathrm{~nm}$ retrieved from MODIS sensors and surface $\mathrm{PM}_{2.5}$ observations for the analysis of aerosol mass mixing ratios at each grid point. Recently, Wang et al. (2013) used the OI within an observing system simulation experiment (OSSE) to investigate the potential impact of future ground-based lidar networks on the analysis and shortterm forecasts of $\mathrm{PM}_{10}$ over Europe. They showed a potentially powerful impact of the future lidar networks for $\mathrm{PM}_{10}$ forecasts. Li et al. (2013) used the OI for multiple aerosol species and for prediction of $\mathrm{PM}_{2.5}$ in the Los Angeles basin. The OI method was also employed in a mesoscale numerical weather prediction system (GRAPES/CUACE_Dust) to study dust aerosol assimilation in eastern Asian (Wang and Niu, 2013). Jiang et al. (2013) developed a DA system in the WRF-Chem model using the OI method to explore the impact of assimilating surface observations of $\mathrm{PM}_{10}$ over China.

The EnKF method was employed to simulate severe dust storm episodes occurring in March 2002 over China by assimilating surface dust concentration observations (Lin et al., 2008). The EnKF method was used to assimilate lidar attenuated backscatter coefficients and depolarisation ratios contained in the CALIPSO Level 1B data set (Sekiyama et al., 2010). Also, a global aerosol assimilation system was developed using the EnKF method for assimilating AOD and AAE (aerosol Ångström exponent) from the AERONET network and the MODIS satellite (Schutgens et al., 2010a, b).

4D-Var was used to assimilate the lidar network Asian dust data (Sugimoto and Uno, 2009). They showed that DA is effective for both improving the model results and estimat- ing the emission in the dust source region. Benedetti et al. (2009) also used the 4D-Var method in the European Centre for Medium-Range Weather Forecasts (ECMWF) for the Global and regional Earth-system Monitoring using Satellite (GEMS) and in situ data project, in order to issue aerosol forecasts and reanalyses of aerosol fields using AOD data from satellite sensors.

In meteorology, OI was surpassed by 4D-Var or EnKF (Kalnay, 2003), but it is still a commonly used DA method in CTMs, as OI is simple to implement and is computationally cheaper than other DA methods (Wu et al., 2008). By contrast, 4D-Var assimilates observations over a time window which could yield better results (Benedetti and Fisher, 2007) when the model is reliable. However, it is more complex to implement because the adjoint of the model is required (Benedetti et al., 2009; Sugimoto and Uno, 2009). Denby et al. (2008), Pagowski and Grell (2012) and Candiani et al. (2013) compared two different DA methods, the OI and the EnKF, for aerosol forecasts. They reported that the EnKF delivers slightly better results than the OI, but the cost of implementation of the EnKF is higher than that of the OI, due to the high number of required model simulations. The OI is then employed in this paper to assimilate observations sequentially.

Several aerosol properties have been assimilated for aerosol forecasts, e.g. surface mass concentrations (Niu et al., 2008; Tombette et al., 2009; Pagowski et al., 2010; Li et al., 2013; Wang and Niu, 2013; Jiang et al., 2013), aerosol particle number size distributions (Viskari et al., 2012), AOD data from satellites or the AERONET network (Huneeus and Boucher, 2007; Adhikary et al., 2008; Benedetti et al., 2009; Schutgens et al., 2010a, b; Liu et al., 2011; Huneeus et al., 2012; Schwartz et al., 2012), lidar backscatter coefficients (Huneeus and Boucher, 2007; Kahnert, 2009; Sekiyama et al., 2010) and lidar extinction coefficients (Campbell et al., 2010; Zhang et al., 2011). Most studies showed fast-fading DA impact on aerosol forecasting, especially in the early forecast hours (Tombette et al., 2009; Jiang et al., 2013). Wang et al. (2013) found that information on the vertical profile can extend the temporal influence of DA. However, in situ surface measurements and AOD data do not provide vertically resolved information in the atmospheric column. Lidar backscatter coefficient profiles provide information on the aerosol vertical structure, but estimating the aerosol backscatter coefficient from single-wavelength elastic lidar signals only (e.g. through the Klett-Fernald method, Klett, 1985) using an a priori value of a lidar ratio (extinction-tobackscatter ratio) brings in errors of up to $30 \%$. No critical assumptions are needed to calculate aerosol backscatter coefficients using the multi-wavelength aerosol lidar (e.g. Raman lidars), typically under nighttime conditions (Ansmann et al., 1992), but most operational lidar stations are singlewavelength lidars. Furthermore, a multi-wavelength aerosol lidar is more costly and mainly dedicated to scientific purposes than a single-wavelength aerosol lidar, and often per- 
forms at one visible light wavelength (e.g. $532 \mathrm{~nm}$ ), which is not eye safe (e.g. aviation near the city). Therefore, it is more realistic to put a single-wavelength aerosol lidar system into operational service. That is why Wang et al. (2014) developed for the first time DA algorithms to assimilate normalised range corrected lidar signals $\left(\mathrm{PR}^{2}\right)$ directly at one wavelength (e.g. $355 \mathrm{~nm})$.

This paper aims at investigating the usefulness of a ground-based lidar network in analysis and short-term forecasts of aerosols based on a case study over the Mediterranean. Important DA algorithm parameters are also studied, e.g. the correlation length in the background error covariance matrix, the altitudes at which DA is performed, and the assimilation period length.

This paper is organised as follows. Section 2 describes the modelling system, i.e. the CTM PolaIR3D/POLYPHEMUs, the OI method and the experiment design. Section 3 provides a description of the observations used. DA parameter tests are conducted in Sect. 4. Results are shown and discussed in Sect. 5. Our findings are summarised in Sect. 6.

\section{Modelling system}

POLAIR3D (Sartelet et al., 2007) is the Eulerian chemistry transport model (CTM) of the POLYPHEMUS air quality platform (Mallet et al., 2007) used to forecast atmospheric compositions such as ozone and PM concentrations (http://cerea. enpc.fr/en/prevision.html, available at http://cerea.enpc.fr/ polyphemus/). The aerosol dynamic is modelled using the SIze-REsolved Aerosol Model (SIREAM-SuperSorgam), which is described in Debry et al. (2007) and Kim et al. (2011). SIREAM-SuperSorgam includes 20 aerosol species: mineral dust, black carbon, ammonium, sulfate, nitrate, chloride, sodium, primary organics and 12 secondary organic species. It models coagulation and condensation/evaporation. Five bins logarithmically distributed over the size range $0.01-10 \mu \mathrm{m}$ are used. The gas chemistry is solved with the CB05 (Carbon Bond version 5) chemical mechanism (Yarwood et al., 2005). PolAIR3D/SIREAM has previously been used for DA using the optimal interpolation (OI) method (Tombette et al., 2009; Wang et al., 2013, 2014).

The aerosol optical property module developed by Wang et al. (2014) is employed. It simulates the molecular backscatter and extinction coefficients $\left(\beta_{\mathrm{m}}\right.$ and $\left.\alpha_{\mathrm{m}}\right)$ from the Boltzmann constant, the atmospheric pressure, and temperature. The aerosol extinction and backscatter coefficients $\left(\beta_{\mathrm{a}}\right.$ and $\alpha_{\mathrm{a}}$ ) are simulated from the model aerosol concentration outputs (i.e. aerosol water content and aerosol) by estimating the particle wet diameter and the aerosol complex refractive index of a particle. Lidar signals (i.e. $\mathrm{PR}^{2}$ normalised at a reference altitude) and AOD are simulated as functions of the molecular backscatter and extinction coefficients and the aerosol extinction and backscatter coefficients.
The modelling domain is the same as the one used for the forecasts at http://cerea.enpc.fr/en/prevision.html. It covers western Europe and parts of eastern Europe $\left(15^{\circ} \mathrm{W}\right.$, $35^{\circ} \mathrm{E} \times 35^{\circ} \mathrm{N}, 70^{\circ} \mathrm{N}$, see Fig. 1), with a horizontal resolution of $0.5^{\circ} \times 0.5^{\circ}$. In the simulation, 14 vertical levels are considered from the ground to an altitude of $12000 \mathrm{~m}$ a.g.l. (above ground level). The heights of the cell interfaces are $0,30,60,100,150,200,300,500,750,1000,1500$, 2400, 3500, 6000 and $12000 \mathrm{~m}$ a.g.l. Meteorological inputs are interpolated from reanalysis provided every $3 \mathrm{~h}$ by the European Centre for Medium-Range Weather Forecasts (ECMWF). Boundary conditions are climatological conditions obtained from averaging boundary conditions from MOZART4 (Model for OZone And Related chemical Tracers version 4) (Emmons et al., 2010) over the years 20042008. Sea-salt emissions are assumed to be made up of $39.33 \%$ of sodium, $55.025 \%$ of chloride and $7.68 \%$ of sulfate, and modelled following Monahan et al. (1986). Anthropogenic emissions of gases and aerosols are generated with the EMEP inventory for 2009. For example, the EMEP provides yearly emissions of $\mathrm{PM}_{2.5}$ and coarse $\mathrm{PM}$ (PM with an aerodynamic diameter higher than $2.5 \mu \mathrm{m}$ but lower than $10 \mu \mathrm{m})$. The $\mathrm{PM}_{2.5}$ fraction is speciated into mineral dust, black carbon and primary organic aerosol. The PM coarse fraction is attributed to mineral dust. In the simulation, Saharan dust is only forced by boundary conditions.

The OI approach is used for assimilating lidar signals from the model aerosol concentration outputs (Wang et al., 2014). The analysed mass concentration $\boldsymbol{x}_{\mathrm{a}}$ is obtained from the equation

$\boldsymbol{x}_{\mathrm{a}}=\boldsymbol{x}_{\mathrm{b}}+\mathbf{B} \mathbf{H}^{\mathrm{T}}\left(\mathbf{H B H}^{\mathrm{T}}+\mathbf{R}\right)^{-1}\left(\boldsymbol{y}-H\left[\boldsymbol{x}_{\mathrm{b}}\right]\right)$,

where $\boldsymbol{x}_{\mathrm{b}}$ are the model mass concentrations, $\boldsymbol{y}$ is the observation vector, $H$ is the observation operator that simulates normalised $\mathrm{PR}^{2}$ from the mass concentrations $\boldsymbol{x}_{\mathrm{b}}, \mathbf{H}$ is the tangent linear operator of $H$, and $\mathbf{B}$ and $\mathbf{R}$ are respectively the background and observation error covariance matrices. Wang et al. (2014) provided two algorithms based on the OI method to compute the analysed state $\boldsymbol{x}_{\mathrm{a}}$. One algorithm analyses $\mathrm{PM}_{10}$ concentrations. The other analyses $\mathrm{PM}_{2.5}$ and $\mathrm{PM}_{10-2.5}$ concentrations separately but simultaneously. Wang et al. (2014) reported that the latter algorithm leads to better forecasts than the former, because the model often simulates $\mathrm{PM}_{2.5}$ better than $\mathrm{PM}_{10-2.5}$, and the background error variances of $\mathrm{PM}_{2.5}$ and $\mathrm{PM}_{10-2.5}$ are set separately in the latter algorithm. Therefore, we employ the latter algorithm in this paper. We set the background error covariance matrix as a block diagonal matrix having two main diagonal blocks. One main diagonal block is set as the background error variance matrix of $\mathrm{PM}_{2.5}$. Another is set as the background error variance matrix of $\mathrm{PM}_{10-2.5}$. We set the background error of $\mathrm{PM}_{2.5}$ and $\mathrm{PM}_{10-2.5}$ at $5 \mu \mathrm{g} \mathrm{m}^{-3}$ and $30 \mu \mathrm{g} \mathrm{m}^{-3}$ respectively in $\mathbf{B}$, since the model simulates $\mathrm{PM}_{2.5}$ more accurately than $\mathrm{PM}_{10-2.5}$ (see Sect. 5). We take 


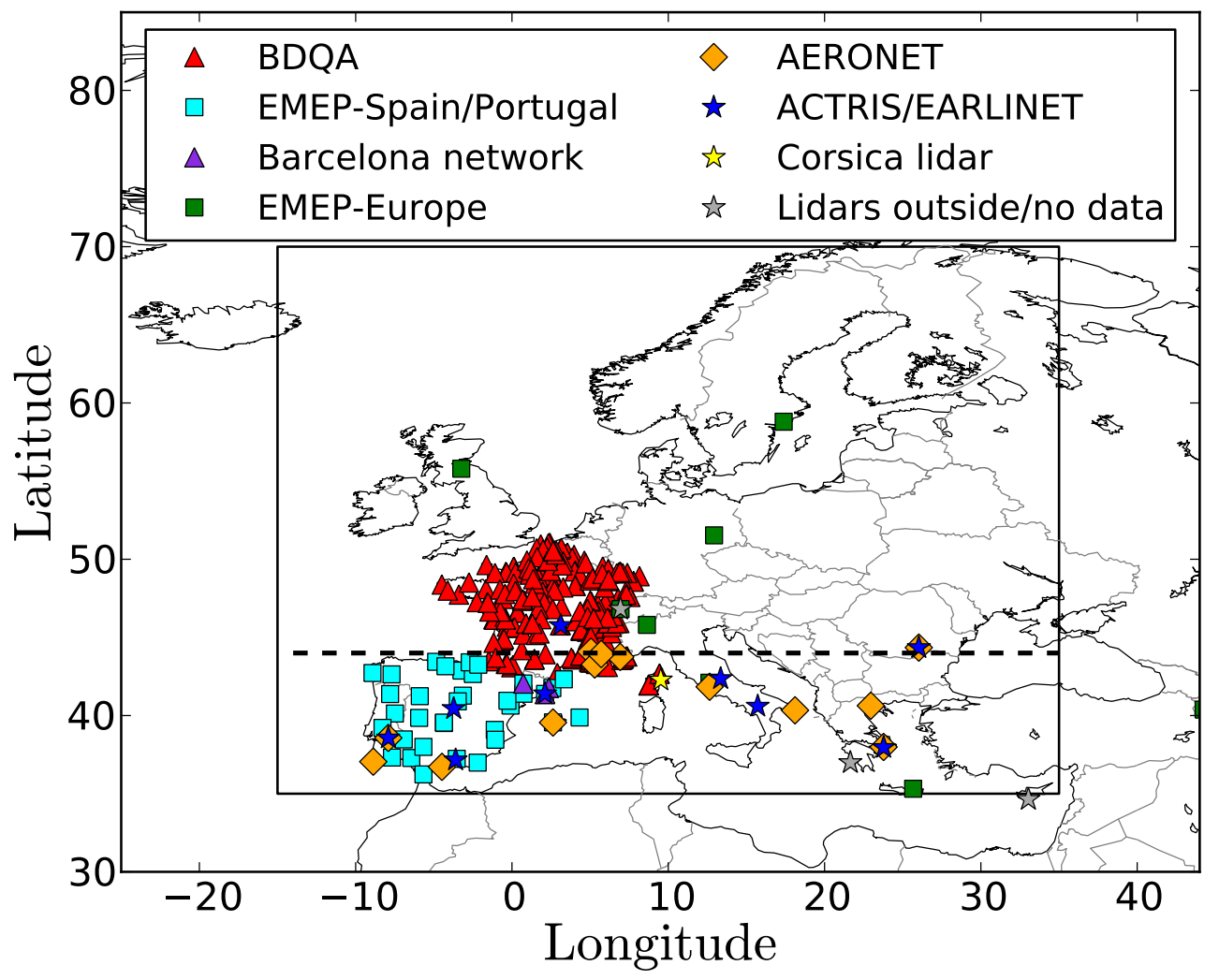

Figure 1. Locations of the different measurement sites used in this paper (see Tables 1 and 3 for the number of stations used in the different networks). The rectangular area delimited by the black box shows our modelling domain. The red triangles indicate the locations of the stations of the French air quality network (BDQA). The cyan squares indicate the locations of the stations of the EMEP-Spain/Portugal network. The violet triangles indicate the locations of the stations around Barcelona. The green squares indicate the locations of the EMEPEurope stations. The orange diamonds indicate the locations of the AERONET stations. The dark blue/grey star markers indicate the locations of ACTRIS/EARLINET stations. The grey star markers indicate lidar stations without data between 9 and 12 July or outside of the forecast domain. The yellow star marker indicates the location of the Corsica lidar station. The dashed line shows the latitude of $44^{\circ} \mathrm{N}$ which is used to split the French stations in Sect. 5.1.

$\mathbf{R}=\sigma^{2} \mathbf{I}$, where $\sigma$ is an observation standard deviation (depending on instrumental and representativeness error variances) and $\mathbf{I}$ is the identity matrix in the observation space. The value of $\sigma$ is different in each DA test. It is determined by a $\chi^{2}$ diagnosis, in which the scalar $\chi^{2}$ at each DA step is defined by

$\chi^{2}=\left(\boldsymbol{y}-H\left[\boldsymbol{x}^{\mathrm{b}}\right]\right)^{\mathrm{T}}\left(\mathbf{H B H}^{\mathrm{T}}+\mathbf{R}\right)^{-1}\left(\boldsymbol{y}-H\left[\boldsymbol{x}^{\mathrm{b}}\right]\right)$.

On average, $\chi^{2}$ should be equal to the number of observations (Ménard et al., 1999). This $\chi^{2}$ diagnosis could balance observation and background errors. After DA, the analysed concentrations are redistributed over the model variables following the initial (background) chemical and size distributions (Tombette et al., 2009; Wang et al., 2013, 2014).

The simulation with DA, referred to as the DA experiment, consists of two periods: an assimilation period and a forecast period. During the assimilation period, at each time step, all available lidar data retrieved in the framework of the pre-ChArMEx (Chemistry-Aerosol Mediterranean Experiment)/TRAQA (TRAnsport à longue distance et Qual- ité de l'Air) and ACTRIS/EARLINET campaigns are assimilated. During the forecast period, DA is not performed. Hence, the model mass concentrations evolve depending on initial and boundary conditions, emissions and meteorology. Concentrations can be impacted by lidar DA far from the place where lidar signals are assimilated, because analysed mass concentrations are transported by winds and diffusion (turbulence).

In regional models, uncertainties are linked to input data and parametrisations, e.g. initial and boundary conditions (Roustan et al., 2010), meteorological inputs (Dawson et al., 2007) and emissions (de Meij et al., 2006; Napelenok et al., 2006). Replacing some input data, such as boundary conditions or emissions, with another set of data which is also uncertain may either improve or deteriorate the aerosol simulations locally, depending on period/year and place. However, DA may be used to improve input data, such as initial conditions, using observations (as done in this paper). The impact of DA may vary locally with the quality of the input data used. 
Table 1. Description of the lidar systems used in this study. "Reso." stands for resolution. "ASL" stands for a.s.l. (altitude above sea level). The letters " $p$ " and "c" in the wavelengths stand for parallel and cross linear polarisation component respectively.

\begin{tabular}{|c|c|c|c|c|c|c|c|}
\hline \multirow{2}{*}{ Lidar site } & \multicolumn{3}{|c|}{ Site coordinates } & \multicolumn{4}{|c|}{ Measurement information } \\
\hline & $\begin{array}{l}\text { Latitude } \\
\text { degree }\end{array}$ & $\begin{array}{l}\text { Longitude } \\
\text { degree }\end{array}$ & $\begin{array}{l}\text { Altitude ASL } \\
\text { meter }\end{array}$ & $\begin{array}{l}\text { Wavelengths } \\
\text { nanometre }\end{array}$ & $\begin{array}{l}\text { Raw range } \\
\text { reso. meter }\end{array}$ & $\begin{array}{l}\text { Raw time } \\
\text { reso. second }\end{array}$ & $\begin{array}{c}\text { Zenith } \\
\text { angle degree }\end{array}$ \\
\hline Athens & 37.96 & 23.78 & 212 & $\begin{array}{l}355,532,1064, \\
387,607\end{array}$ & 7.5 & 100 & 0 \\
\hline Barcelona & 41.389 & 2.112 & 115 & $\begin{array}{l}355,532,1064 \\
387,607\end{array}$ & 3.75 & 60 & 52 \\
\hline Bucharest & 44.348 & 26.029 & 93 & $\begin{array}{l}355,532 \mathrm{c}, 532 \mathrm{p} \\
1064,387,607\end{array}$ & 3.75 & 60 & 0 \\
\hline Clermont-Ferrand & 45.761 & 3.111 & 420 & $355 \mathrm{c}, 355 \mathrm{p}, 387$ & 7.5 & 60 & 0 \\
\hline Evora & 38.568 & -7.912 & 290 & $\begin{array}{l}355,532 \mathrm{c}, 532 \mathrm{p} \\
1064,387,607\end{array}$ & 30 & 30 & 5 \\
\hline Granada & 37.164 & -3.605 & 680 & $\begin{array}{l}355,532 \mathrm{c}, 532 \mathrm{p} \\
1064,387,607\end{array}$ & 7.5 & 60 & 0 \\
\hline L'Aquila & 42.368 & 13.351 & 656 & 351,382 & 30 & 300 & 0 \\
\hline Madrid & 40.456 & 3.726 & 669 & $\begin{array}{l}355,532,1064 \\
387,607\end{array}$ & 7.5 & 60 & 0 \\
\hline Potenza & 40.601 & 15.723 & 760 & $\begin{array}{l}355,532 \mathrm{c}, 532 \mathrm{p} \\
1064,387,607\end{array}$ & 3.75 & 60 & 0 \\
\hline Corsica & 42.280 & 9.520 & 50 & 355 & 15 & 50 & 15 \\
\hline Limassol* & 33.040 & 34.640 & 8 & $532,607,1064,532 p$ & 7.5 & 48 & 0 \\
\hline Messinia* & 21.649 & 36.993 & 3 & $532,532 p$ & 7.5 & 60 & 0 \\
\hline Payerne* & 6.943 & 46.813 & 491 & $355,387,407$ & 3.25 & 60 & 0 \\
\hline
\end{tabular}

* Limassol was not included, because it is outside of the model domain. Payerne and Messinia were not included, because data were not available.

Table 2. DA tests with different configurations for the evaluation of the impact of the assimilation parameters on the forecasts. $L_{\mathrm{h}}$ is the horizontal correlation length used in the Balgovind approach (Balgovind et al., 1983) to define the error covariance matrix $\mathbf{B}$.

\begin{tabular}{llc}
\hline Simulation name & $L_{\mathrm{h}}$ in $\mathbf{B}$ & Assimilation altitude range \\
\hline DA $L_{\mathrm{h}}=50 \mathrm{~km}$ & $50 \mathrm{~km}$ & $1.0-3.5 \mathrm{~km}$ a.g.l. \\
DA $L_{\mathrm{h}}=100 \mathrm{~km}$ & $100 \mathrm{~km}$ & $1.0-3.5 \mathrm{~km}$ a.g.l. \\
DA $L_{\mathrm{h}}=200 \mathrm{~km}$ & $200 \mathrm{~km}$ & $1.0-3.5 \mathrm{~km}$ a.g.l. \\
DA $0.75-3.5 \mathrm{~km}$ & $100 \mathrm{~km}$ & $0.75-3.5 \mathrm{~km}$ a.g.l. \\
DA $1.5-3.5 \mathrm{~km}$ & $100 \mathrm{~km}$ & $1.5-3.5 \mathrm{~km}$ a.g.l. \\
\hline
\end{tabular}

\section{Observations}

In the following, we describe the observations used in this study: the lidar signals used for assimilation, and surface mass concentrations and AOD used for the DA validation.

\subsection{Lidar observations}

An intensive measurement effort was performed by 12 ground-based lidar stations from the ACTRIS/EARLINET network (Bösenberg et al., 2003; Pappalardo et al., 2014) in the Mediterranean basin and one station in Corsica in the framework of the pre-ChArMEx/TRAQA and ACTRIS/EARLINET campaigns in July 2012 during $72 \mathrm{~h}$. All stations were located on the northern side of the Mediterranean. One of the goals of this campaign was to locate and track aerosols in the lower and middle troposphere in the Mediterranean region and to help improve our forecast ability of CTMs using DA. The ground-based lidar stations (blue/grey and yellow star markers in Fig. 1) performed continuous measurements from 9 July at 06:00 UTC until 12 July at 06:00 UTC. The participating EARLINET stations include Athens, Barcelona, Bucharest, Evora, Granada, L'Aquila, Limassol, Madrid, Messinia, Potenza, Payerne and ClermontFerrand. The MISTRALS/ChArMEx station was situated at INRA (Institut National de la Recherche Agronomique), San Giuliano, at about $3 \mathrm{~km}$ from the eastern coastline of Corsica (see Fig. 1). Data received by the Payerne and Messinia stations are not available. Also, data received by the Limassol station are not used in this paper, because Limassol is outside of the model domain.

Table 1 shows the site coordinates and properties of the lidar systems used in this campaign. The vertical resolution of measurements ranges from $3.25 \mathrm{~m}$ to $30 \mathrm{~m}$ (depending on the lidar system). The temporal resolution of measurements ranges from $30 \mathrm{~s}$ to $300 \mathrm{~s}$ (depending on the lidar system). The raw data (except those of the Corsica station) were automatically treated by the single calculus chain (SCC) developed by the EARLINET lidar network (http: //www.earlinetasos.org) (D'Amico et al., 2012) to generate integrated profiles of range-corrected lidar signals $\left(\mathrm{PR}^{2}\right)$ in 

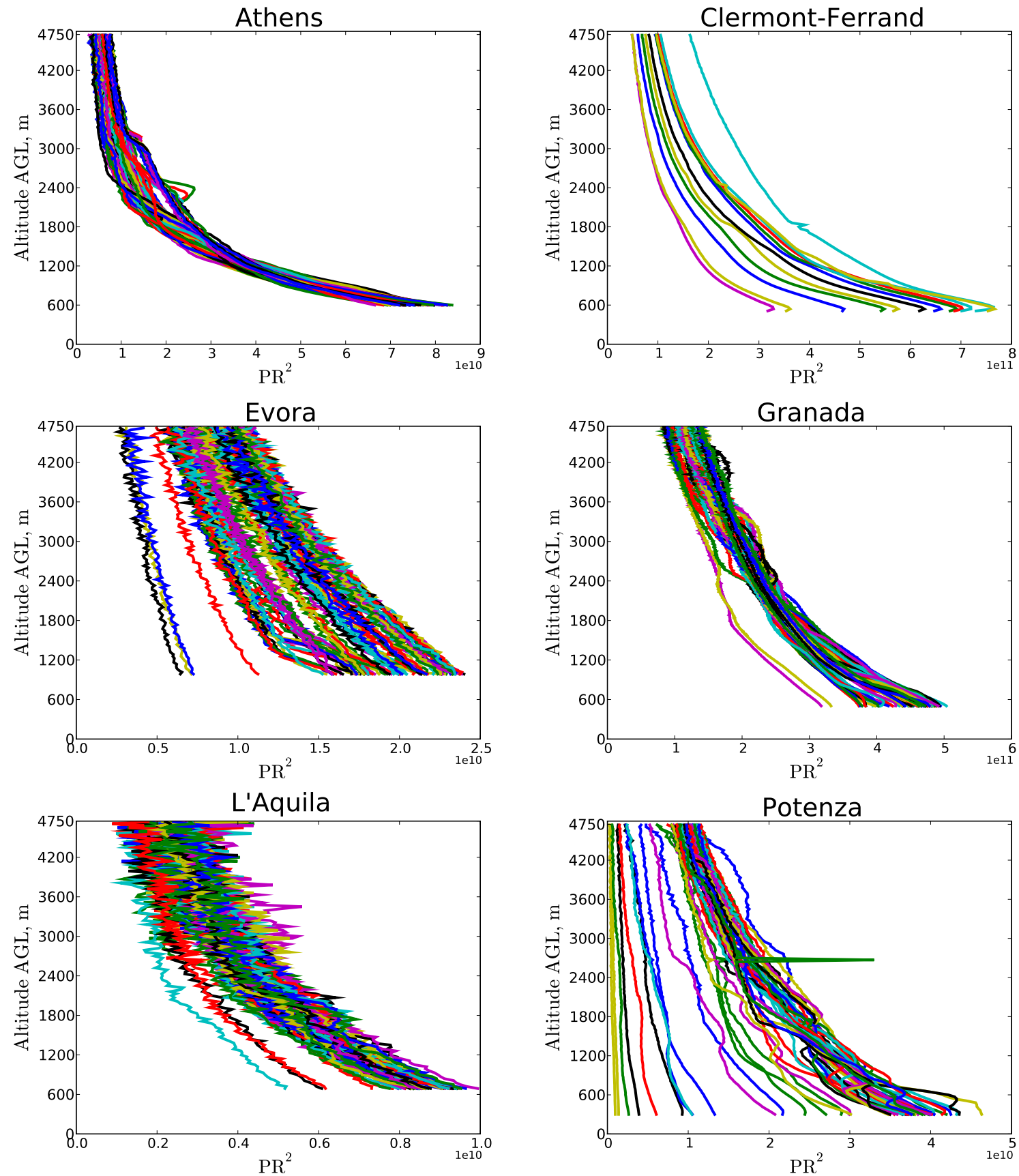

Figure 2. Hourly averaged range-corrected lidar signals $\left(\mathrm{PR}^{2}\right)$ from 06:00 UTC 9 July to 06:00 UTC 12 July at the Athens, Clermont-Ferrand, Evora, Granada, L'Aquila and Potenza lidar stations.

near real time under cloud-free conditions. The SCC is an automatic tool to get different types of aerosol products (e.g. $\mathrm{PR}^{2}$, aerosol extinction and backscatter coefficients) from raw lidar data. In this work, only one type of the available products, $\mathrm{PR}^{2}$, is used. All observations are integrated with a time resolution of $1 \mathrm{~h}$, the DA time step used in this study, and normalised at an altitude in the range of the molecular zone. It is because there is almost no aerosol in the molecu- lar zone. The linear approximation of the observed lidar signal should be equal to the one of the simulated molecular signal (without aerosol contribution) in the molecular zone (Wang et al., 2014). In this paper, it is taken at $4750 \mathrm{~m}$ a.g.l., which corresponds to the model level of 3500-6000 km a.g.l. (see Sect. 2). Figure 2 shows $\mathrm{PR}^{2}$ at the Athens, ClermontFerrand, Evora, Granada, L'Aquila and Potenza lidar stations. Those at the other stations are shown later, in Fig. 3. 

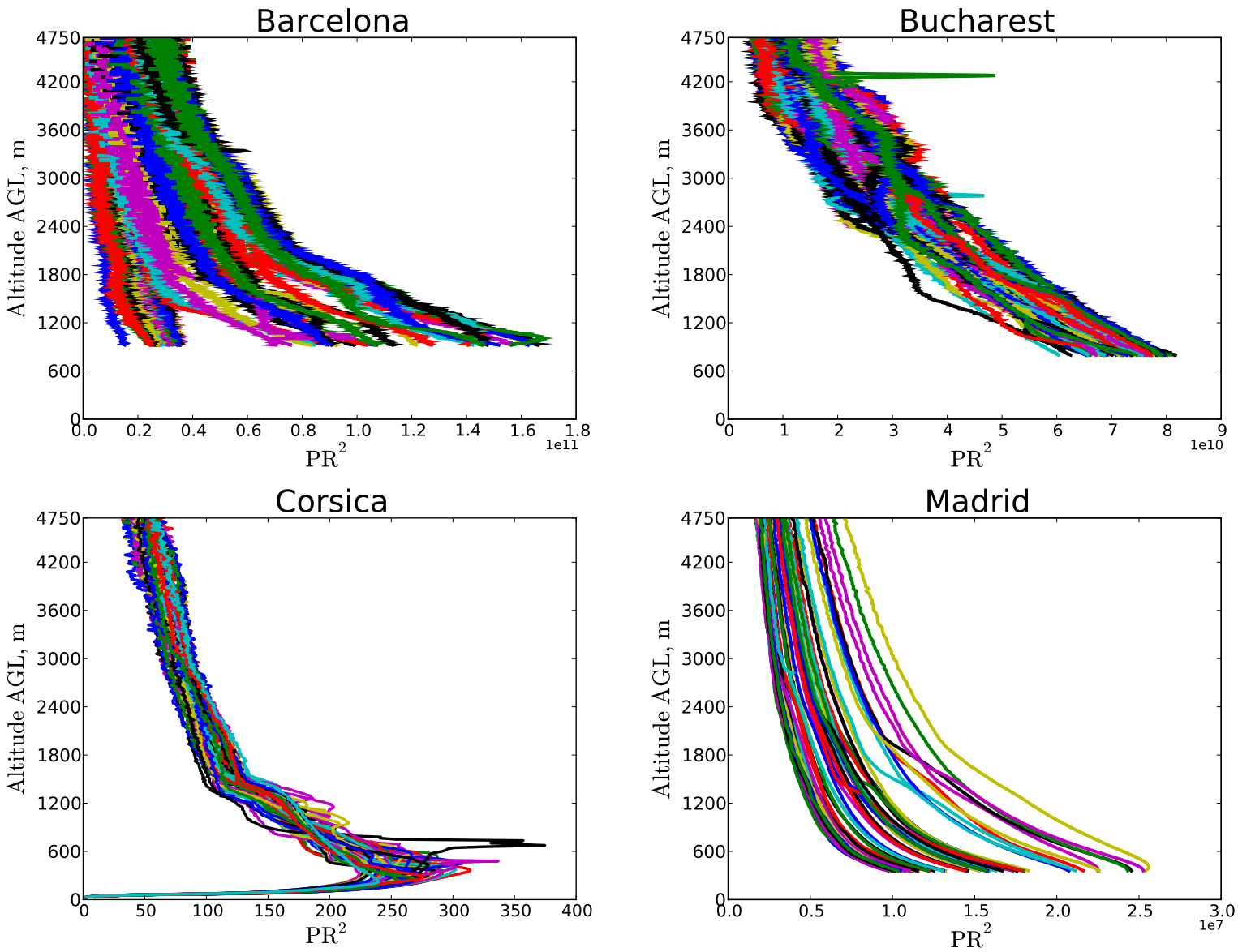

Figure 3. Hourly averaged range-corrected lidar signals $\left(\mathrm{PR}^{2}\right)$ from 06:00 UTC 9 July to 06:00 UTC 12 July at the Barcelona, Bucharest, Corsica and Madrid lidar stations.

Table 3. Number of stations used for $\mathrm{PM}_{2.5}, \mathrm{PM}_{10}$ or AOD in the different networks.

\begin{tabular}{llll}
\hline \multirow{2}{*}{ Network name } & \multicolumn{3}{l}{ Number of stations used } \\
& $\mathrm{PM}_{10}$ & $\mathrm{PM}_{2.5}$ & AOD \\
\hline BDQA & 240 & 70 & 0 \\
Barcelona & 3 & 3 & 0 \\
EMEP-Europe & 7 & 0 & 0 \\
EMEP-Spain/Portugal & 22 & 0 & 0 \\
AERONET & 0 & 0 & 13 \\
\hline
\end{tabular}

\subsection{Observations for validation}

We employ two independent data types for DA validation: surface mass concentration measurements (i.e. $\mathrm{PM}_{2.5}$ and $\mathrm{PM}_{10}$ ) and AOD data.

The surface mass concentration measurements are from the BDQA (Base de Données sur la Qualité de l'Air, the French national database for air quality which covers France) network, the Barcelona network (three stations), the EMEPSpain/Portugal network, and the EMEP-Europe database (see Fig. 1). The French and Barcelona networks (triangles in Fig. 1) provide hourly averaged mass concentration measurements of $\mathrm{PM}_{2.5}$ and $\mathrm{PM}_{10}$. The EMEP-Spain/Portugal and EMEP-Europe networks (squares in Fig. 1) provide daily averaged mass concentration measurements of $\mathrm{PM}_{10}$. The number of used stations in the BDQA, Barcelona, EMEP-Europe and EMEP-Spain/Portugal networks, which provide $\mathrm{PM}_{10}$ or $\mathrm{PM}_{2.5}$ measurements in July 2012, is shown in Table 3 . The BDQA network provides the most measurements, with 240 stations for $\mathrm{PM}_{10}$ and 70 stations for $\mathrm{PM}_{2.5}$.

The hourly AOD data at $355 \mathrm{~nm}$ are derived by level 2.0 (cloud-screened and quality-assured) AOD data at 340 and $380 \mathrm{~nm}$ retrieved from AERONET (AErosol RObotic NETwork, http://aeronet.gsfc.nasa.gov/) following the Ångström law (Wang et al., 2014). The locations of the AERONET stations considered (e.g. stations that are close to the lidar network and that provide the level 2.0 AOD data in the pre-ChArMEx/TRAQA and ACTRIS/EARLINET campaign) are shown as orange diamonds in Fig. 1. Thirteen AERONET stations are used for validation in this paper (see Table 3). 

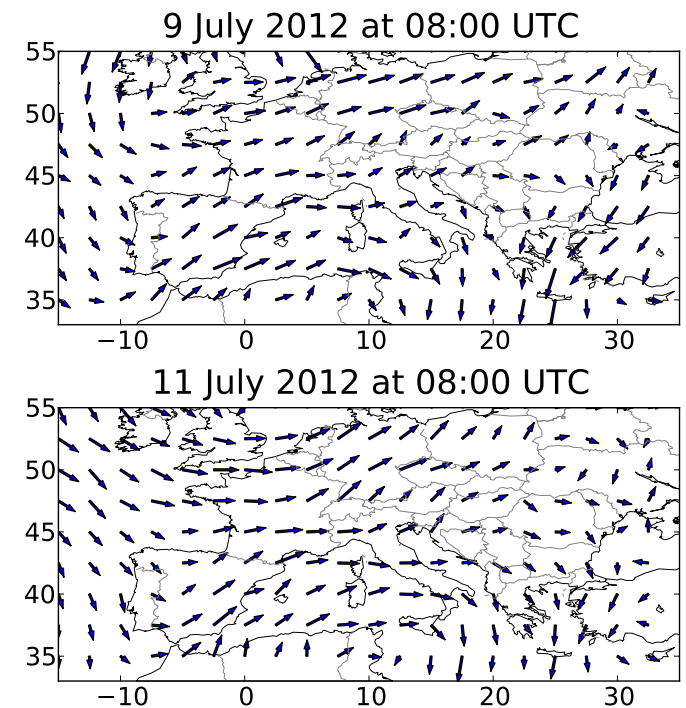

10 July 2012 at 08:00 UTC

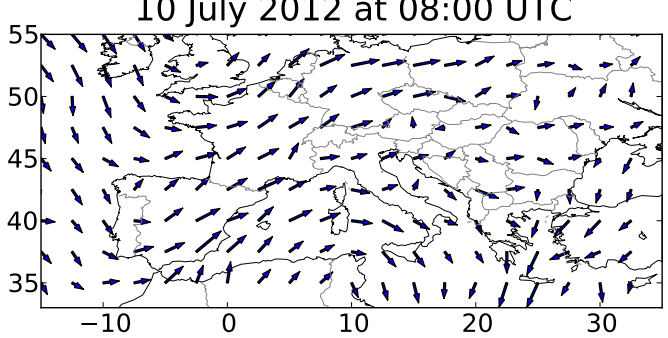

12 July 2012 at $08: 00$ UTC

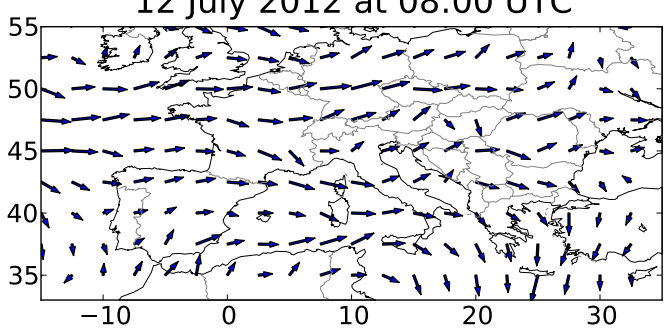

Figure 4. Wind fields (arrows) at about $2 \mathrm{~km}$ a.g.1. at 08:00 UTC on 9, 10, 11 and 12 July 2012. The data are interpolated from ECMWF fields.

\subsection{Case study}

The Mediterranean basin is the receptacle of aerosols from different origins, e.g. biogenic emissions, natural dust emissions from the Sahara (Moulin et al., 1998; Hamonou et al., 1999), anthropogenic emissions from highly populated coastal areas, marine aerosols, and wildfires. Emissions from anthropogenic and biogenic origins strongly interact to form secondary organic aerosols (Sartelet et al., 2012). The aerosol load is often high over the Mediterranean region (Putaud et al., 2010; Nabat et al., 2013). Therefore, it is a good place to test the usefulness of lidar DA to improve the forecast of CTMs.

Figure 4 shows wind fields at about $2 \mathrm{~km}$ a.g.l. interpolated from ECMWF data for each morning of the lidar measurement period, i.e. 9 July 2012 at 08:00 UTC, 10 July 2012 at 08:00 UTC, 11 July 2012 at 08:00 UTC, and 12 July 2012 at 08:00 UTC. Westerly or northerly winds transported pollution over the Mediterranean during the lidar campaign. Figure 5 shows the AODs at $550 \mathrm{~nm}$ retrieved from MSG (Meteosat Second Generation)/SEVIRI satellites (http://www. icare.univ-lille1.fr/msg/, Thieuleux et al., 2005) $15 \mathrm{~min}$ image averaged from all available images between 04:00 and 18:00 UTC on 9-12 July 2012, where the high AODs observed mainly in the southern part of the Mediterranean were mostly due to Saharan dust. However, penetration of the Saharan dust plume over the continent of Europe was limited, except in the south of Italy and the south and east of Spain. At the Ersa surface station in Corsica, the chemical analysis of filters from 00:00 until 12:00 UTC on 11 July 2012 did not detect Saharan dust (Nicolas, 2013), and the MISTRALS/ChArMEx aerosol lidar in Corsica does not show evidence of a dust layer (see Fig. 3).
To check that the penetration of the Saharan dust plume over the continent of Europe was limited, and to assess where analysed concentrations are transported to after assimilation, Fig. 6 shows $48 \mathrm{~h}$ backward trajectories (dashed lines) of air masses arriving at $2 \mathrm{~km}$ a.g.l. and $72 \mathrm{~h}$ forward trajectories (solid lines) of air masses departing at $2 \mathrm{kma.g} .1$. at 10 lidar stations. These data are outputs of the Hybrid Single Particle Lagrangian Integrated Trajectory (HYSPLIT; http://ready.arl.noaa.gov/HYSPLIT.php) model (Draxler and Rolph, 2014; Rolph, 2014) using the Global Data Assimilation System (GDAS) meteorological data with a resolution of $1^{\circ} \times 1^{\circ}$. These backward (forward) trajectories end (start) respectively at 06:00 UTC on 9 July 2012, 10 July 2012, 11 July 2012 and 12 July 2012. They indicate that aerosols measured in Spain, Portugal and France were transported to the northeast or east. Aerosols measured by lidars at other stations (i.e. Athens, L'Aquila, Potenza, and Bucharest) were transported to the south or east. Those observations are in agreement with wind fields shown in Fig. 4. In addition, there is almost no rainfall along trajectories (not shown in this paper).

\section{Assimilation parameter tests}

In this section, we perform sensitivity tests, first on the DA period length, and then on the horizontal correlation length used in the background error covariance matrix and on the assimilation altitude range.

\subsection{Assimilation period length}

Wang et al. (2013) compared the aerosol forecasts performed after different assimilation periods varying from $6 \mathrm{~h}$ 

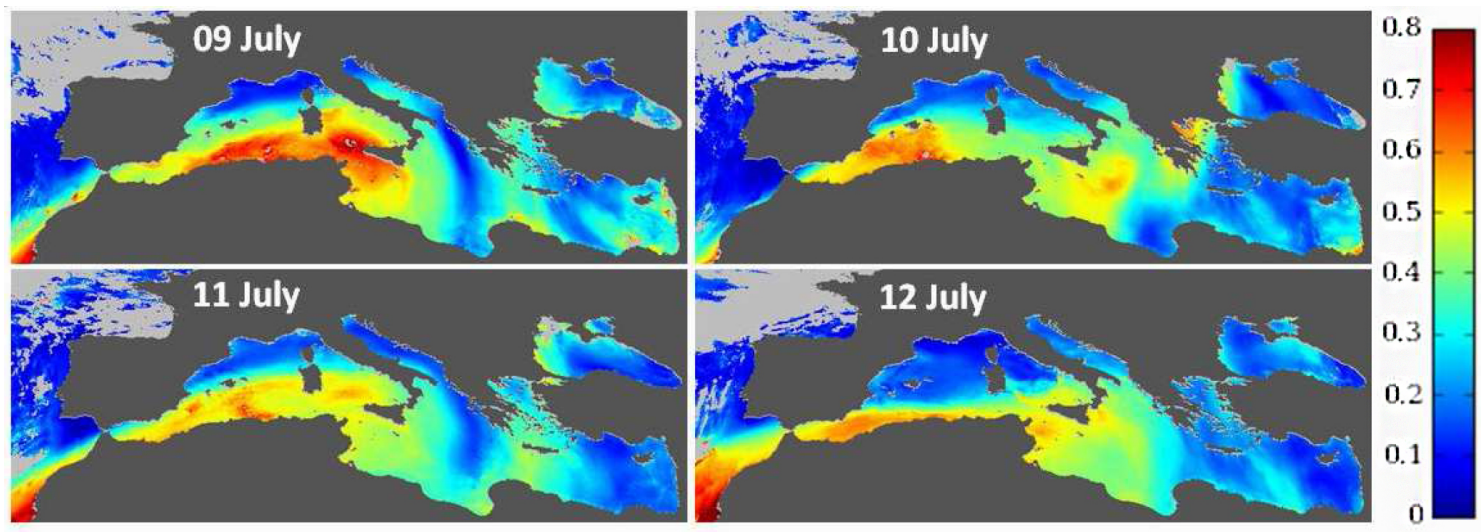

Figure 5. Daytime (from 04:00 to 18:00 UTC) mean AOD at $550 \mathrm{~nm}$ derived from MSG/SEVIRI.

Table 4. Statistics (see Appendix A) of the simulation results for the different networks.

\begin{tabular}{|c|c|c|c|c|c|c|c|c|c|}
\hline Network & Species & Simulation & Stations & $\begin{array}{l}\text { Obs. }^{1} \text { mean } \\
\mu \mathrm{g} \mathrm{m}^{-3}\end{array}$ & $\begin{array}{r}\operatorname{Sim}^{2} \text { mean } \\
\mu \mathrm{g} \mathrm{m} \mathrm{m}^{-3}\end{array}$ & $\begin{array}{r}\text { RMSE } \\
\mu \mathrm{g} \mathrm{m}^{-3}\end{array}$ & $\begin{array}{r}\text { Corr. }^{3} \\
\%\end{array}$ & $\begin{array}{r}\text { MFB } \\
\%\end{array}$ & $\begin{array}{c}\text { MFE } \\
\%\end{array}$ \\
\hline \multirow[t]{4}{*}{ BDQA } & \multirow{2}{*}{$\mathrm{PM}_{10}$} & Without DA & 240 & 14.1 & 9.8 & 8.8 & 40 & -26 & 44 \\
\hline & & With DA & & & 11.4 & 8.0 & 49 & -14 & 40 \\
\hline & \multirow{2}{*}{$\mathrm{PM}_{2.5}$} & Without DA & 70 & 8.1 & 7.9 & 4.4 & 39 & 11 & 43 \\
\hline & & With DA & & & 8.5 & 4.3 & 44 & 17 & 44 \\
\hline \multirow[t]{4}{*}{ Barcelona } & \multirow[t]{2}{*}{$\mathrm{PM}_{10}$} & Without DA & 3 & 22.2 & 15.1 & 8.9 & $\mathrm{Nan}^{4}$ & -37 & 39 \\
\hline & & With DA & & & 20.1 & 7.0 & $\mathrm{Nan}^{4}$ & -6 & 26 \\
\hline & \multirow{2}{*}{$\mathrm{PM}_{2.5}$} & Without DA & 3 & 17.0 & 12.5 & 6.0 & $\mathrm{Nan}^{4}$ & -27 & 33 \\
\hline & & With DA & & & 14.5 & 4.7 & $\mathrm{Nan}^{4}$ & -11 & 24 \\
\hline \multirow[t]{2}{*}{ EMEP-Spain/Portugal } & \multirow[t]{2}{*}{$\mathrm{PM}_{10}$} & Without DA & 22 & 16.0 & 12.8 & 6.9 & 58 & 22 & 24 \\
\hline & & With DA & & & 13.7 & 6.3 & 63 & 15 & 17 \\
\hline
\end{tabular}

1 “Obs." stands for observation. ${ }^{2}$ "Sim." stands for simulation. ${ }^{3}$ "Corr." stands for correlation. ${ }^{4}$ Correlation is not presentable for three stations.

to 3 days, during which surface mass concentration observations were assimilated. They suggested that an assimilation period of $12 \mathrm{~h}$ is necessary to improve the aerosol forecast. In this work, two DA period lengths, $12 \mathrm{~h}$ and $24 \mathrm{~h}$, are employed to study the impact of the assimilation period length on aerosol forecasting. The results are detailed in this section.

The $72 \mathrm{~h}$ period of continuous lidar measurements from 06:00 UTC 9 July to 06:00 UTC 12 July 2012 is split into three experiments of $24 \mathrm{~h}$ each. For the assimilation period of 12 (or 24) hours, for each of the three experiments, the lidar data are assimilated during 12 (or 24) hours, and $60 \mathrm{~h}$ forecasts are issued at 06:00 UTC on 10, 11 and 12 July, respectively. All DA experiments use the same parameters (i.e. the horizontal correlation length is $100 \mathrm{~km}$ and the assimilation altitude ranges from 1.0 to $3.5 \mathrm{~km}$ a.g.l.), except for the assimilation period length.

Figure 7 shows the scores, the RMSE (root mean square error) and the (Pearson) correlation calculated against the ground observations over France (the BDQA network) for
$\mathrm{PM}_{10}$ and $\mathrm{PM}_{2.5}$, since the BDQA network provides most measurements of $\mathrm{PM}_{10}$ and $\mathrm{PM}_{2.5}$. We refer to Appendix A for the definition of statistical indicators. Overall, the simulation with lidar DA leads to better scores than the simulation without DA during the first $36 \mathrm{~h}$ of forecast. The improvements in DA are significant for $\mathrm{PM}_{10}$. The RMSE (or correlation) of $\mathrm{PM}_{10}$ averaged over the first $36 \mathrm{~h}$ of forecast is $9.4 \mu \mathrm{g} \mathrm{m}^{-3}$ (or $39 \%$ ) without DA, $8.4 \mu \mathrm{g} \mathrm{m}^{-3}$ (or $49 \%$ ) with $12 \mathrm{~h} \mathrm{DA}$ and $8.4 \mu \mathrm{g} \mathrm{m}^{-3}$ (or $50 \%$ ) with $24 \mathrm{~h}$ DA. For $\mathrm{PM}_{2.5}$, the improvements in DA are not significant, except for the correlation. The RMSE (or correlation) of $\mathrm{PM}_{2.5}$ averaged over the first $36 \mathrm{~h}$ of forecast is $4.5 \mu \mathrm{g} \mathrm{m}^{-3}$ (or $37 \%$ ) without DA and $4.4 \mu_{\mathrm{g} \mathrm{m}}^{-3}$ (or $43 \%$ ) with either $12 \mathrm{~h} \mathrm{DA}$ or with $24 \mathrm{~h}$ DA. Comparing DA with $24 \mathrm{~h}$ of analysis (DA test " $24 \mathrm{~h}$ DA") to $12 \mathrm{~h}$ of analysis (DA test " $12 \mathrm{~h}$ DA"), the simulation with $24 \mathrm{~h}$ of analysis delivers slightly better scores during the forecast period (to the right of the black lines). However, the difference between DA tests " $24 \mathrm{~h}$ DA" and " $12 \mathrm{~h}$ DA" after $6 \mathrm{~h}$ forecasts is barely significant. Since the measurement period of the lidar campaign in July 2012 lasted only $72 \mathrm{~h}$, and 

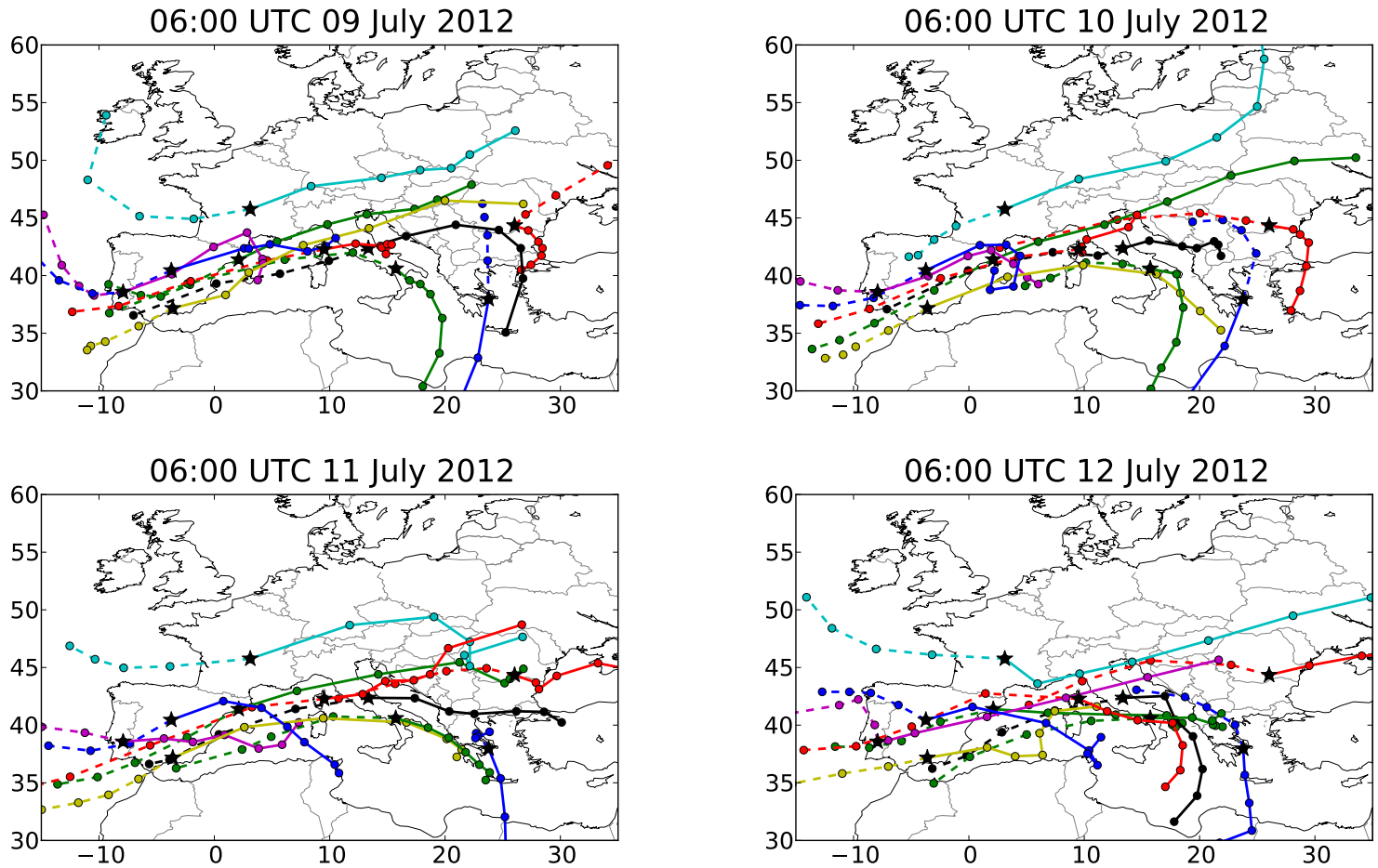

Figure 6. Backward (forward) trajectories of $48 \mathrm{~h}(72 \mathrm{~h})$ at lidar site locations (black stars) at $2 \mathrm{~km} \mathrm{a.g.1.} \mathrm{ending} \mathrm{(or} \mathrm{starting)} \mathrm{at} \mathrm{06:00} \mathrm{UTC}$ 9 July 2012, 06:00 UTC 10 July 2012, 06:00 UTC 11 July 2012 and 06:00 UTC 12 July 2012. Data are from the HYSPLIT model. Dashed (solid) lines indicate backward (forward) trajectories, where the $12 \mathrm{~h}$ spacing is given by the discs. The backward trajectories pertain to the source attribution problem of the lidar measurements, whereas the forward trajectories show the propagation of the DA updates around lidar locations.

the simulation with $24 \mathrm{~h}$ of analysis does not lead to much better scores than the one with $12 \mathrm{~h}$ of analysis during the forecast period, we chose to perform DA experiments with an assimilation period of $12 \mathrm{~h}$ in the following to have sufficient DA experiments to evaluate the results of DA statistically. In this case, the $72 \mathrm{~h}$ period of continuous lidar measurements is split into six $12 \mathrm{~h}$ assimilation periods (should $24 \mathrm{~h}$ DA be chosen, the $72 \mathrm{~h}$ period of continuous lidar measurements would be split into only three disjoint $24 \mathrm{~h}$ assimilation periods). Figure 8 shows the schematic representation of these six DA experiments. Each DA experiment includes a $12 \mathrm{~h}$ assimilation period (grey bars) and a $60 \mathrm{~h}$ forecast period (white bars). All DA experiments begin either at 06:00 UTC or at 18:00 UTC on 9, 10 or 11 July 2012. Figure 9 shows the schematic representation of the lidar measurement segments assimilated in six DA experiments. At each DA step, all available lidar data retrieved from 10 lidar stations are assimilated.

\subsection{Assimilation correlation length}

In Table 2, the different configurations of DA are summarised, with the horizontal correlation length $L_{\mathrm{h}}$ (e.g. 50, 100 and $200 \mathrm{~km}$ ) and the assimilation altitude range used. The scores (i.e. RMSE and correlation) of the different con- figurations of DA for $\mathrm{PM}_{10}$ and $\mathrm{PM}_{2.5}$ are shown in Fig. 10. These scores are calculated against the observations of the BDQA network. In this section, the impact of the horizontal correlation length $L_{\mathrm{h}}$ of the error covariance matrix $\mathbf{B}$ is studied, since $L_{\mathrm{h}}$ is an important parameter that determines to what horizontal extent the particle concentrations are corrected by DA.

At the beginning of the assimilation period, all simulations have the same scores, since the simulations without DA and with DA use the same initial conditions. The improvement in aerosol mass concentrations at stations over France starts $6 \mathrm{~h}$ after the start of the DA experiment. This delay is due to the fact that the only lidar station in France used for this study is in Corsica, away from continental France (see Figs. 4 and 6; the station in Clermont-Ferrand provided too few observations due to bad weather during the campaign, see Fig. 9). It is also because the assimilation altitude range is high: it starts higher than $1.0 \mathrm{~km}$ a.g.l. The analysed mass concentrations therefore take time to be transported to the ground level. We find that the correlation length $L_{\mathrm{h}}=200 \mathrm{~km}$ (yellow lines in Fig. 10) is too large, decreasing slightly the correlation coefficients for both $\mathrm{PM}_{10}$ and $\mathrm{PM}_{2.5}$ at French stations during the assimilation period (to the left of the black lines in Fig. 10). 

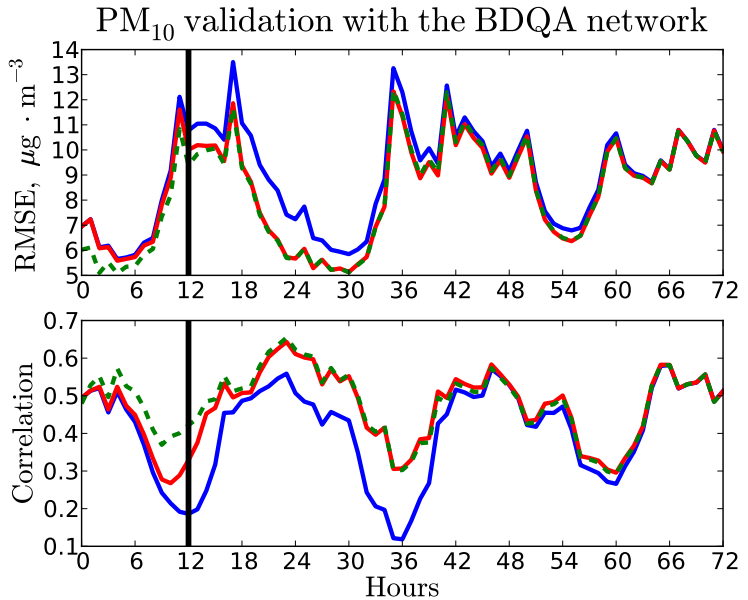

$\mathrm{PM}_{2.5}$ validation with the BDQA network
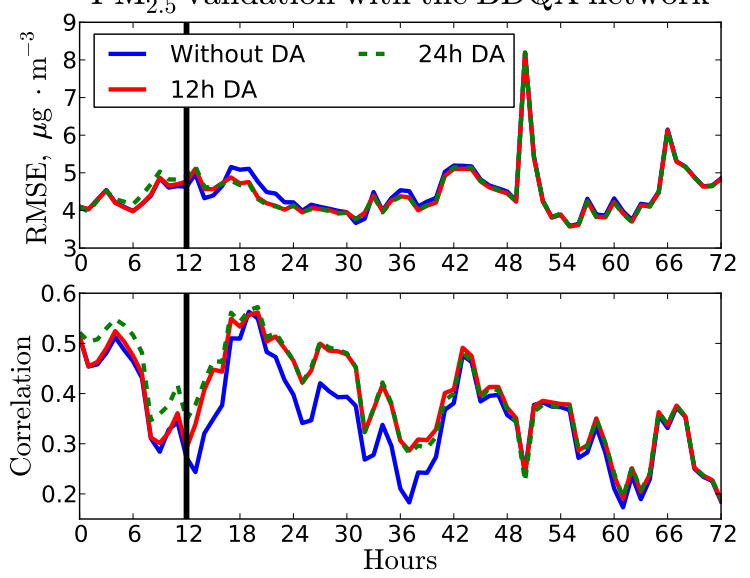

Figure 7. The top (or bottom) panel shows the time evolution of the RMSE $\left(\mu \mathrm{g} \mathrm{m}^{-3}\right.$ ) and the correlation of $\mathrm{PM}_{10}$ (or $\mathrm{PM}_{2.5}$ ) averaged over the different DA experiments for three experiment types: one without DA, one with $12 \mathrm{~h}$ of DA and one with $24 \mathrm{~h}$ of DA. The scores are computed for the BDQA network (hourly data). The vertical black lines denote the separation between the assimilation period (to the left of the black lines) and the forecast (to the right of the black lines). "12 DA" ("24 DA") stands for DA with 12 (24) hours of analysis. The forecasts of " 12 DA" and " 24 DA" start at the same moment. The scores in the first 12 analysis hours of " 24 DA" are not shown.

During the forecast period (to the right of the black lines in Fig. 10), the temporal impact of the assimilation of lidar signals lasts longer than $36 \mathrm{~h}$ for all DA tests. Notice that the temporal impact of assimilating surface mass concentrations was estimated to be between 6 and $12 \mathrm{~h}$ (Tombette et al., 2009; Jiang et al., 2013). The comparison of the DA tests with $L_{\mathrm{h}}=50 \mathrm{~km}$ (green lines in Fig. 10), $L_{\mathrm{h}}=100 \mathrm{~km}$ (red lines in Fig. 10) and $L_{\mathrm{h}}=200 \mathrm{~km}$ (yellow lines in Fig. 10) shows that using $L_{\mathrm{h}}=100 \mathrm{~km}$ leads to better forecasts than using $L_{\mathrm{h}}=50 \mathrm{~km}$ or $L_{\mathrm{h}}=200 \mathrm{~km}$ on the first forecast day. In addition, using $L_{\mathrm{h}}=200 \mathrm{~km}$ (yellow lines in Fig. 10) results in a higher RMSE than the simulation without DA for

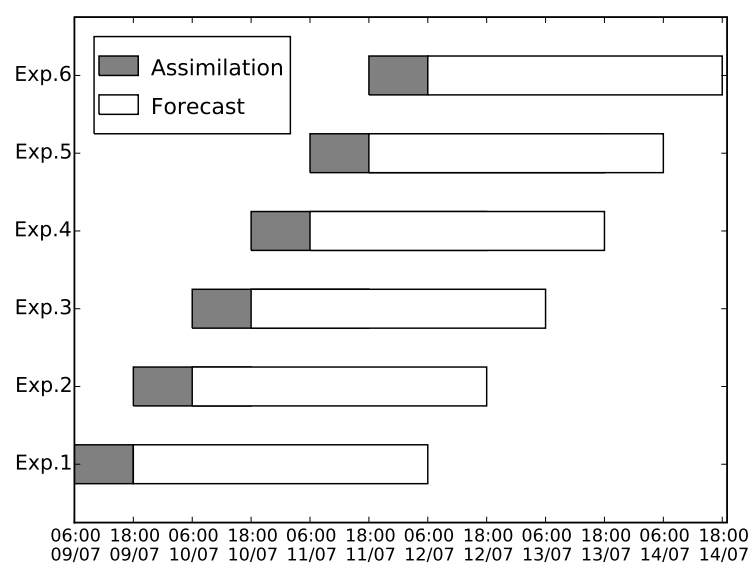

Figure 8. Schematic representation of six DA experiments with a $12 \mathrm{~h}$ assimilation period (grey colour) and a $60 \mathrm{~h}$ forecast period (white colour). "Exp." stands for DA experiment.

$\mathrm{PM}_{2.5}$ on the first forecast day. This is because the analysed zone in the model is set to be isotropic (a horizontal disc, the centre of the disc being the measurement station, i.e. the lidar site), whereas the analysed zone should be horizontally anisotropic, depending on the wind direction and the aerosol spatial distribution (e.g. aerosol origins). Using $L_{\mathrm{h}}=200 \mathrm{~km}$ defines an isotropic analysed zone which is too large, leading to a decrease in correlation coefficients. On the second forecast day, using $L_{\mathrm{h}}=200 \mathrm{~km}$ leads to much better scores than using $L_{\mathrm{h}}=50 \mathrm{~km}$ or $L_{\mathrm{h}}=100 \mathrm{~km}$ for both $\mathrm{PM}_{10}$ and $\mathrm{PM}_{2.5}$. Moreover, the beneficial impact of the assimilation with $L_{\mathrm{h}}=200 \mathrm{~km}$ lasts longer than $48 \mathrm{~h}$. It is because using $L_{\mathrm{h}}=200 \mathrm{~km}$ leads to higher corrections around the lidar site due to the use of the Balgovind approach (Balgovind et al., 1983) (the closer to the lidar site the grid point is, the higher the correlation is). The corrections due to the higher correlation around lidar sites (far away from France) are more accurate, and impact France later.

\subsection{Assimilation altitude range}

The choice of the assimilation altitude range is influenced by two factors. First, as the normalisation of range-corrected lidar signals is done at high altitudes, the lower the altitude is, the higher the error in the simulated lidar signal is. It is mostly because the integration of simulated extinction coefficients from the considered altitude to the normalisation altitude leads to accumulation of errors of simulated lidar signals at high altitudes, especially in the case where highaltitude aerosol layers are not well modelled (Wang et al., 2014). Second, the numerical computations of the lidar operator $H$ and its tangent lidar operator $\mathbf{H}$ (see Eq. 1) are very costly. The larger the assimilation altitude range is, the more costly the numerical computation is. Hence, in this section, we investigate the impact of the assimilation altitude range on aerosol forecasting. 

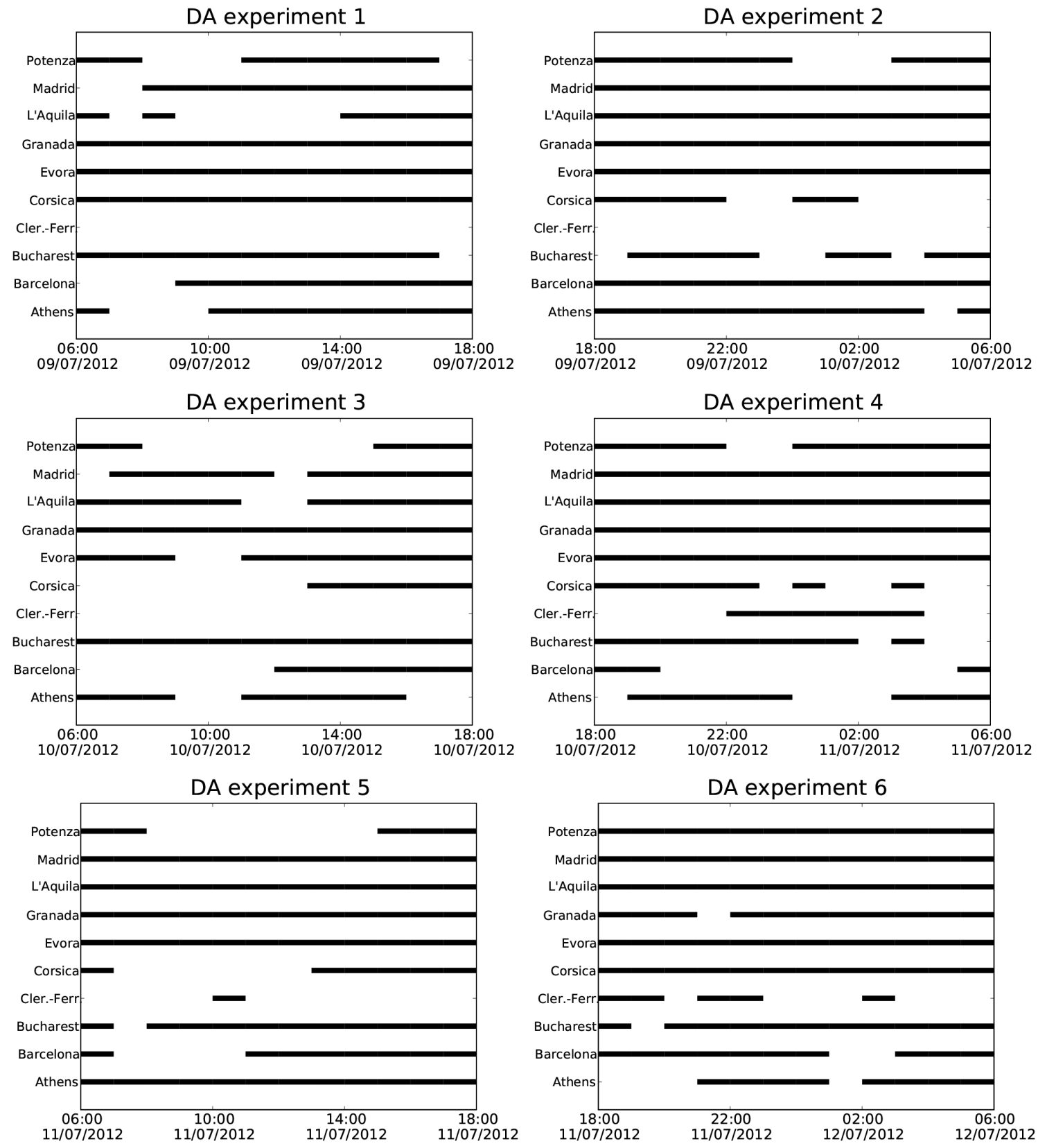

Figure 9. Schematic representation of the lidar measurement segments assimilated (black segments) during the assimilation period for six DA experiments. "Cler.-Ferr." stands for Clermont-Ferrand.

We perform three DA tests $(0.75-3.5 \mathrm{~km}$ a.g.1., 1.5 $3.5 \mathrm{~km}$ a.g.1. and a reference case $1.0-3.5 \mathrm{~km}$ a.g.l. in Fig. 10). As shown in Fig. 10, assimilating lidar signals from 0.75 to $3.5 \mathrm{~km}$ a.g.l. (magenta lines) leads to similar scores (with respect to hourly data of BDQA) as assimilating from 1.0 to $3.5 \mathrm{~km}$ a.g.l. (a reference case, red lines). A first explanation is that the observation variance (sum of instrumental and representativeness variances, from the $\chi^{2}$ diagnosis) of the model level of $0.75-1.0 \mathrm{~km}$ a.g.l. is set higher than those of the model levels from 1.0 to $3.5 \mathrm{~km}$ a.g.l. A second ex- planation is that the scores in Fig. 10 are computed using the observations from the BDQA network, where most improvements are from assimilation of lidar signals in Spain or Portugal (see Figs. 4 and 6). However, of the lidar stations in Spain, only Madrid and Granada provided data between 0.75 and $1.0 \mathrm{~km}$ a.g.l. (see Figs. 2 and 3). In addition, assimilating lidar signals from 1.0 to $3.5 \mathrm{~km}$ a.g.l. (magenta lines) leads to slightly better scores than from 1.5 to $3.5 \mathrm{~km}$ a.g.l. (black lines). 

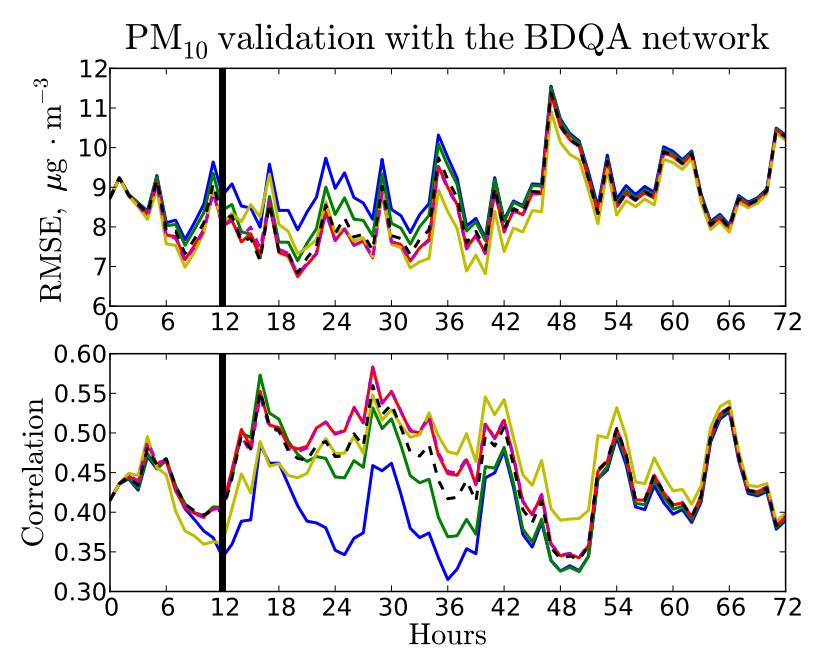

$\mathrm{PM}_{2.5}$ validation with the BDQA network
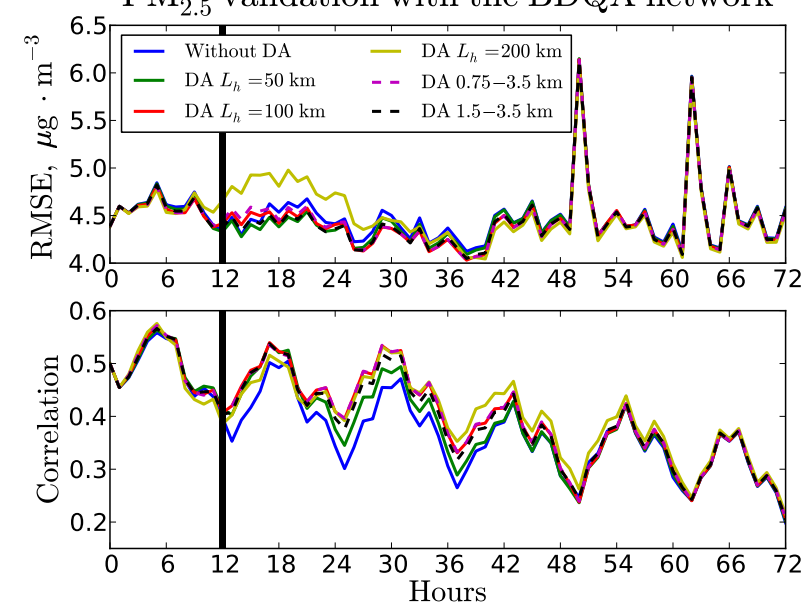

Figure 10. The top (or bottom) panel shows the time evolution of the RMSE $\left(\mu \mathrm{g} \mathrm{m}^{-3}\right.$ ) and the correlation of $\mathrm{PM}_{10}$ (or $\mathrm{PM}_{2.5}$ ) averaged for each of the six different experiments. The scores are computed for the BDQA network (hourly data). The vertical black lines denote the separation between the $12 \mathrm{~h}$ assimilation period (to the left of the black lines) and the $60 \mathrm{~h}$ forecast period (to the right of the black lines). The "DA $L_{\mathrm{h}}=50 \mathrm{~km}$ ", "DA $L_{\mathrm{h}}=100 \mathrm{~km}$ " and "DA $L_{\mathrm{h}}=200 \mathrm{~km}$ " simulations correspond to an assimilation altitude range from 1.0 to $3.5 \mathrm{~km}$. The "DA $0.75-3.5 \mathrm{~km}$ " and "DA $1.5-3.5 \mathrm{~km}$ " simulations correspond to $L_{\mathrm{h}}=100 \mathrm{~km}$.

\section{Results and discussions}

The US Environmental Protection Agency (EPA) has issued minimal guidance on PM model performance evaluation measures, goals, and criteria. Boylan and Russell (2006) suggested using the mean fractional bias (MFB, \%) and the mean fractional error (MFE, \%), because they bound the maximum bias and error (see Appendix A). We evaluate the simulation without DA using the hourly observations from the French BDQA network with these criteria. For $\mathrm{PM}_{10}$ (or $\mathrm{PM}_{2.5}$ ), the MFB and MFE averaged over all six experiments are respectively $-29 \%$ and $46 \%$ (or $6 \%$ and $43 \%$ ). For both $\mathrm{PM}_{10}$
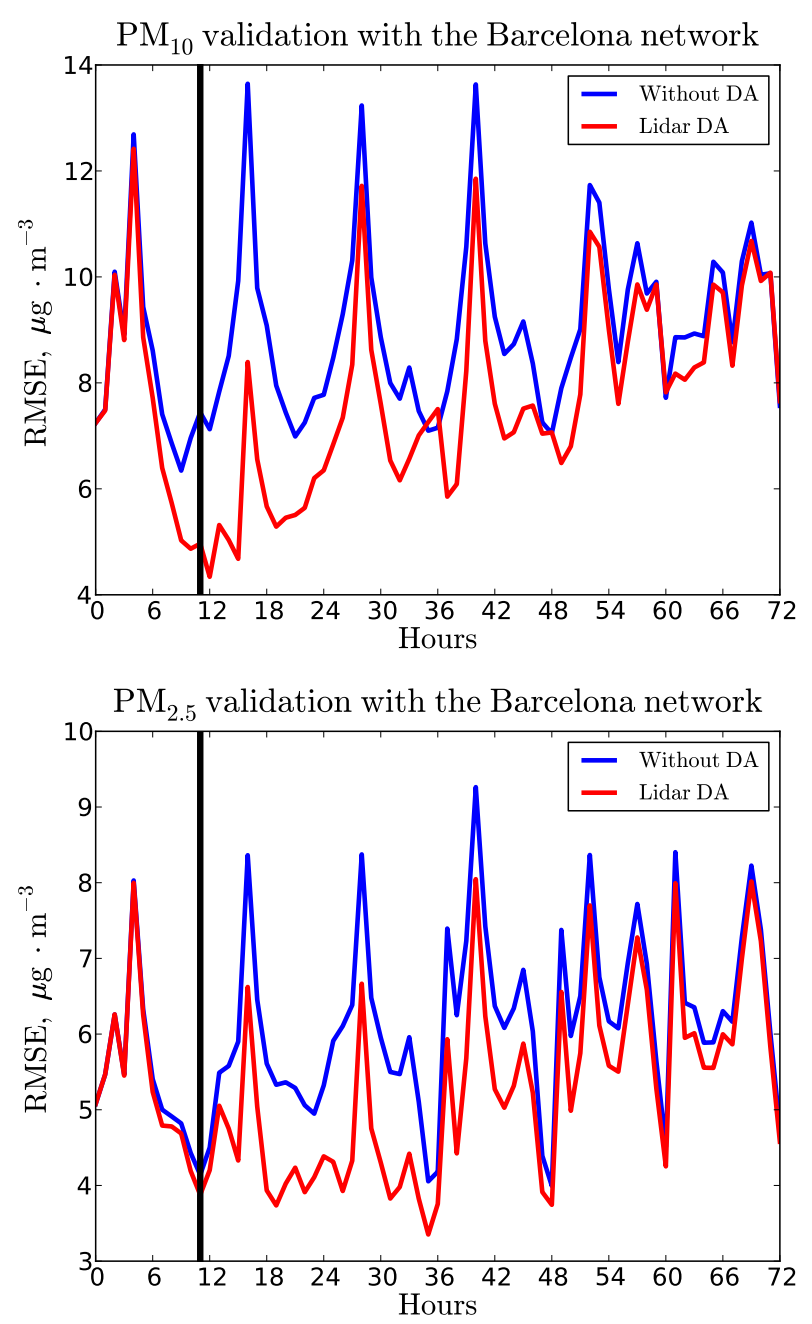

Figure 11. The top (or bottom) panel shows the time evolution of the RMSE $\left(\mu \mathrm{g} \mathrm{m}^{-3}\right)$ of $\mathrm{PM}_{10}\left(\right.$ or $\left.\mathrm{PM}_{2.5}\right)$ averaged over the different experiments without and with DA $\left(L_{\mathrm{h}}=100 \mathrm{~km}\right.$ and altitude range $1.0-3.5 \mathrm{~km}$ ). For the six successive experiments, the time origin corresponds respectively to 06:00 UTC on 9 July, 18:00 UTC on 9 July, 06:00 UTC on 10 July, 18:00 UTC on 10 July, 06:00 UTC on 11 July and 18:00 UTC on 11 July. The scores are computed for three stations around Barcelona (hourly data, see Fig. 1). The vertical black lines denote the separation between the $12 \mathrm{~h}$ assimilation period (to the left of the black lines) and the $60 \mathrm{~h}$ forecast period (to the right of the black lines).

and $\mathrm{PM}_{2.5}$, the criteria evaluation goals are verified. However, the model simulates $\mathrm{PM}_{2.5}$ better than $\mathrm{PM}_{10}$, which is slightly underestimated. This is probably because road resuspension of PM is not considered, either in the model or in the input data (e.g. boundary conditions). As a consequence, we have set a lower standard deviation for $\mathrm{PM}_{2.5}$ (i.e. $5 \mu \mathrm{g} \mathrm{m}^{-3}$ ) than for $\mathrm{PM}_{10-2.5}$ (i.e. $30 \mu \mathrm{g} \mathrm{m}^{-3}$ ) in the background error covariance matrix B (see Eq. 1). 


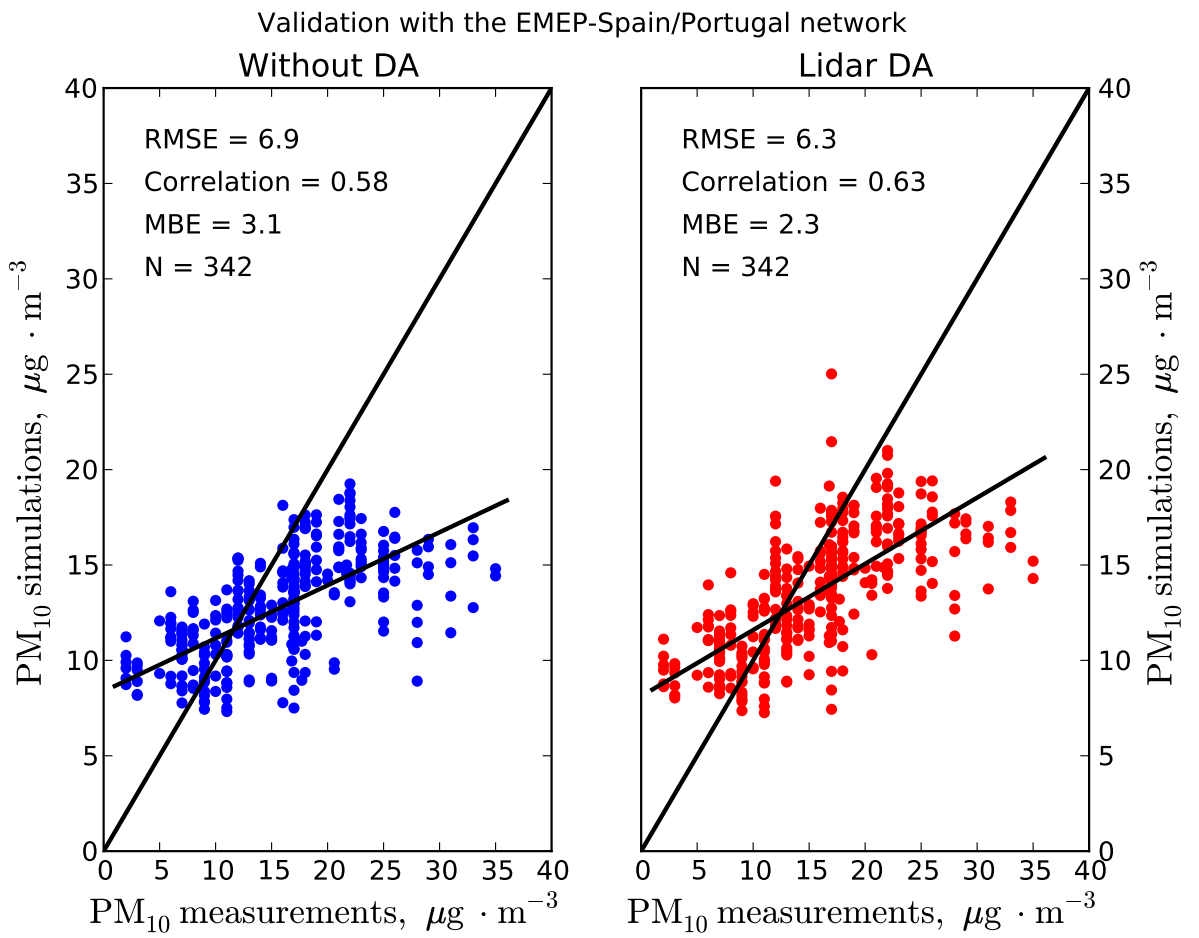

Figure 12. Scatter plots of simulated $\mathrm{PM}_{10}$ mass concentrations without DA (left panel) and with DA (right panel) against daily PM 10 measurements at several EMEP-Spain/Portugal stations.
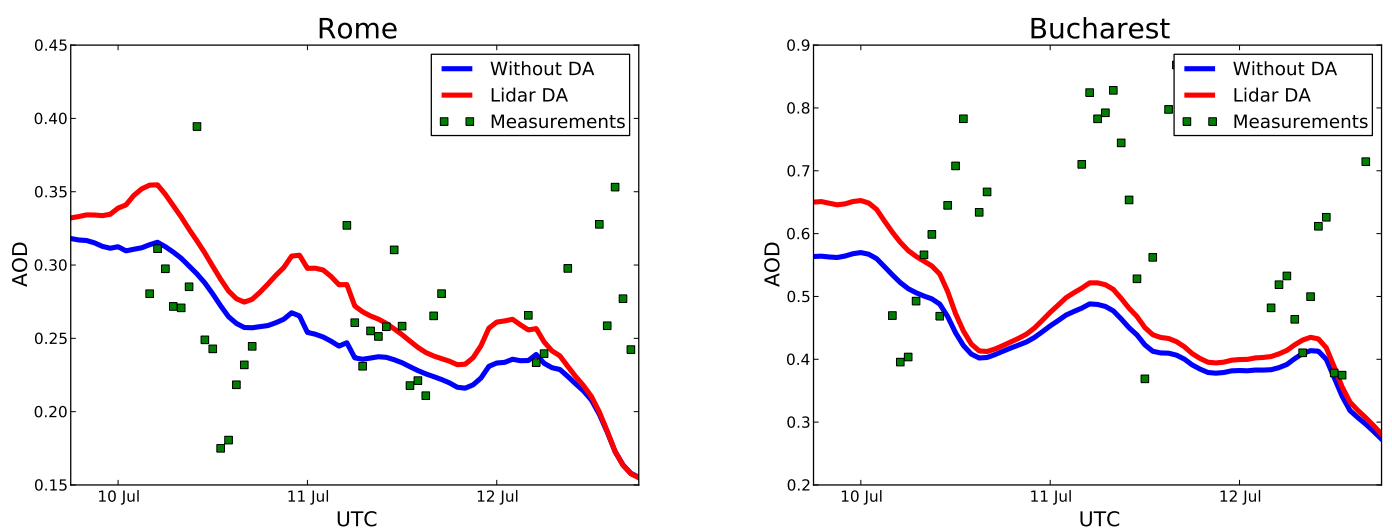

Figure 13. Time evolution of the hourly averaged measured AODs (green dots) and simulated AODs without DA (blue lines) and with DA (red lines) over the first $36 \mathrm{~h}$ forecast period, at the AERONET stations of Rome and Bucharest.

As discussed in Sect. 4, the "DA $L_{\mathrm{h}}=100 \mathrm{~km}$ " DA test, which assimilates lidar signals retrieved from the lidar campaign from 1.0 to $3.5 \mathrm{~km}$ a.g.l. during $12 \mathrm{~h}$ with $L_{\mathrm{h}}=$ $100 \mathrm{~km}$, and which performs $60 \mathrm{~h}$ forecasts, delivers the best scores during the forecast period. Therefore, in the following, we consider the "DA $L_{\mathrm{h}}=100 \mathrm{~km}$ " DA test ("Lidar DA" hereafter). Since most improvements are in the first $36 \mathrm{~h}$ of forecast, we compute the scores only for this period hereafter, instead of for the whole forecast period (i.e. $60 \mathrm{~h}$ ).

\subsection{Validation with the BDQA network}

For $\mathrm{PM}_{10}$, the averaged RMSE (correlation) over the first $36 \mathrm{~h}$ of forecast is $8.8 \mathrm{\mu g} \mathrm{m}^{-3}(40 \%)$ without DA and $8.0 \mu \mathrm{g} \mathrm{m}^{-3}$ (49\%) with DA (see Table 4). For $\mathrm{PM}_{2.5}$, the averaged RMSE (correlation) over the first $36 \mathrm{~h}$ of forecast is $4.4 \mu \mathrm{g} \mathrm{m}^{-3}$ (39\%) without DA and $4.3 \mu \mathrm{g} \mathrm{m}^{-3}(44 \%)$ with DA (see Table 4). Notice that DA improves PM $_{10}$ more efficiently than $\mathrm{PM}_{2.5}$. Therefore, DA would be very useful in reducing the uncertainties in the simulation due to road resuspension of coarse PM. However, these improvements are not 
very significant, especially for $\mathrm{PM}_{2.5}$, because most BDQA stations are far away from the lidar network. Improvements are more significant when using only stations in the south of France.

Against the observations at BDQA stations on the southern side of $44^{\circ} \mathrm{N}$ (dashed line in Fig. 1), the averaged RMSE (MFB and MFE respectively) of $\mathrm{PM}_{10}$ over the first $36 \mathrm{~h}$ of forecast is $16.4 \mathrm{\mu g} \mathrm{m}^{-3}$ (-53\% and $30 \%$ respectively) without DA and $13.7 \mu \mathrm{g} \mathrm{m}^{-3}$ (-26\% and $46 \%$ respectively) with DA. For PM 2.5 , the averaged RMSE (MFB and MFE respectively) over the first $36 \mathrm{~h}$ of forecast is $7.1 \mu \mathrm{g} \mathrm{m}^{-3}$ ( $-20 \%$ and $47 \%$ respectively) without DA and $6.5 \mu \mathrm{g} \mathrm{m}^{-3}$ ( $-6 \%$ and $44 \%$ respectively) with DA. The improvements in DA are more significant by comparisons to measurements at BDQA stations south of $44^{\circ} \mathrm{N}$ than at all the BDQA stations. Aerosol forecasts over these southern stations are impacted by DA of the Corsica, Spain and Portugal lidar data (see Fig. 6).

Moreover, we compare simulations with DA in the daytime (DA is performed from 06:00 to 18:00 UTC) to simulations with DA in the nighttime (DA is performed from 18:00 to $06: 00$ UTC). We find that they lead to similar scores (results not shown in this paper).

\subsection{Validation with the Barcelona network}

Figure 11 shows the time evolution of the RMSE averaged over all six experiments without and with lidar DA for $\mathrm{PM}_{10}$ and $\mathrm{PM}_{2.5}$. The RMSEs are computed at three surface stations around the Barcelona lidar station (violet triangles in Fig. 1). We find that the impact of the assimilation of lidar signals is longer than $48 \mathrm{~h}$ in the forecast period for both $\mathrm{PM}_{10}$ and $\mathrm{PM}_{2.5}$. The averaged RMSE of $\mathrm{PM}_{10}$ over the first $36 \mathrm{~h}$ of forecast is $8.9 \mathrm{\mu g} \mathrm{m}^{-3}$ without DA and $7.0 \mu \mathrm{g} \mathrm{m}^{-3}$ with DA (see Table 4). The averaged RMSE of $\mathrm{PM}_{2.5}$ over the first $36 \mathrm{~h}$ of forecast is $6.0 \mu \mathrm{g} \mathrm{m}^{-3}$ without DA and $4.7 \mu \mathrm{g} \mathrm{m}^{-3}$ with DA (see Table 4). We find that the aerosol error reduction around Barcelona is higher than the one over France and the south of France (estimated using the BDQA network). That is because the surface stations around Barcelona are close to the ground-based Barcelona lidar station, leading to larger benefits of DA. Furthermore, the surface stations around Barcelona are also strongly influenced by the Evora and Madrid lidar sites due to wind fields, because Barcelona is on the leeward side of these lidar sites during the lidar campaign in July 2012 (see Fig. 6). The improvements due to lidar DA associated with long-range transport of pollution from Evora and Madrid are also validated.

\subsection{Validation with the EMEP-Spain/Portugal network}

Figure 12 shows the scatter plots of simulated $\mathrm{PM}_{10}$ concentrations without and with DA against $\mathrm{PM}_{10}$ daily measurements at EMEP-Spain/Portugal stations (cyan squares in Fig. 1). The $\mathrm{PM}_{10}$ correlation and RMSE are slightly im- proved. During the assimilation and forecast periods $(72 \mathrm{~h})$, the RMSE averaged over all six experiments is $6.9 \mu \mathrm{g} \mathrm{m}^{-3}$ without DA and $6.3 \mu \mathrm{g} \mathrm{m}^{-3}$ with DA (see Table 4). Compared to the simulations without DA, DA ("Lidar DA") increases the correlation from $58 \%$ to $63 \%$ (see Table 4). Meanwhile, the mean bias error (MBE) decreases from 3.1 to $2.3 \mu \mathrm{g} \mathrm{m}^{-3}$ (see Fig. 12). Also, we compute the statistics of the simulation results without and with DA using daily concentrations at all EMEP-Europe stations (seven stations, green squares in Fig. 1). However, since EMEP-Europe stations are far away from the lidar network, the $\mathrm{PM}_{10}$ RMSE, correlation and bias are slightly but barely improved (not shown).

\subsection{Validation with the AERONET network}

Figure 13 shows the time evolution of the AOD measurements and AODs of the $36 \mathrm{~h}$ forecasts without DA and with DA at AERONET stations Rome $\left(41.84^{\circ} \mathrm{N}, 12.65^{\circ} \mathrm{E}, 130 \mathrm{~m}\right.$ a.g.l.) and Bucharest $\left(44.35^{\circ} \mathrm{N}, 26.03^{\circ} \mathrm{E}, 93 \mathrm{~m}\right.$ a.g.l.). The impact of assimilating lidar signals lasts about $36 \mathrm{~h}$, which corresponds to the findings of Sects. 5.1 and 5.2.

Figure 14 shows the scatter plots of simulated AODs without and with DA against AOD from hourly measurements of the AERONET network over the first $36 \mathrm{~h}$ of forecast, where only 13 AERONET stations leeward and close to the lidar network are considered (see Fig. 1). As shown by comparing the left panels of Figs. 12 and 14, the model simulates AOD better than $\mathrm{PM}_{10}$. This is mostly because the model simulates fine particles $\left(\mathrm{PM}_{2.5}\right)$ better over the modelling domain (horizontal and vertical), and $\mathrm{PM}_{2.5}$ tends to have larger contributions to optical properties than coarse particles when no Saharan dust event occurs (Chazette et al., 2005; Randriamiarisoa et al., 2006). This is also probably because the model may simulate the integrated mass concentration better than vertically resolved mass concentrations.

As shown in Fig. 14, AODs are significantly improved in the simulation with DA for high AOD observations (few cases). When the observed AODs are larger than $0.4(N=$ 262), the RMSE (MBE) is $0.23(0.2)$ without DA against $0.20(0.13)$ with lidar DA. It is because large AODs could be associated with transport of particles above the boundary layer, which is not well simulated by the model (probably due to large-scale model uncertainties), but which is followed by the lidars (Wang et al., 2014). It may also be that assimilation of lidar signals improves the estimation of aerosol mass concentrations more efficiently when aerosol concentrations are high, e.g. during air pollution events, that is, when the lidar signal is strong. 

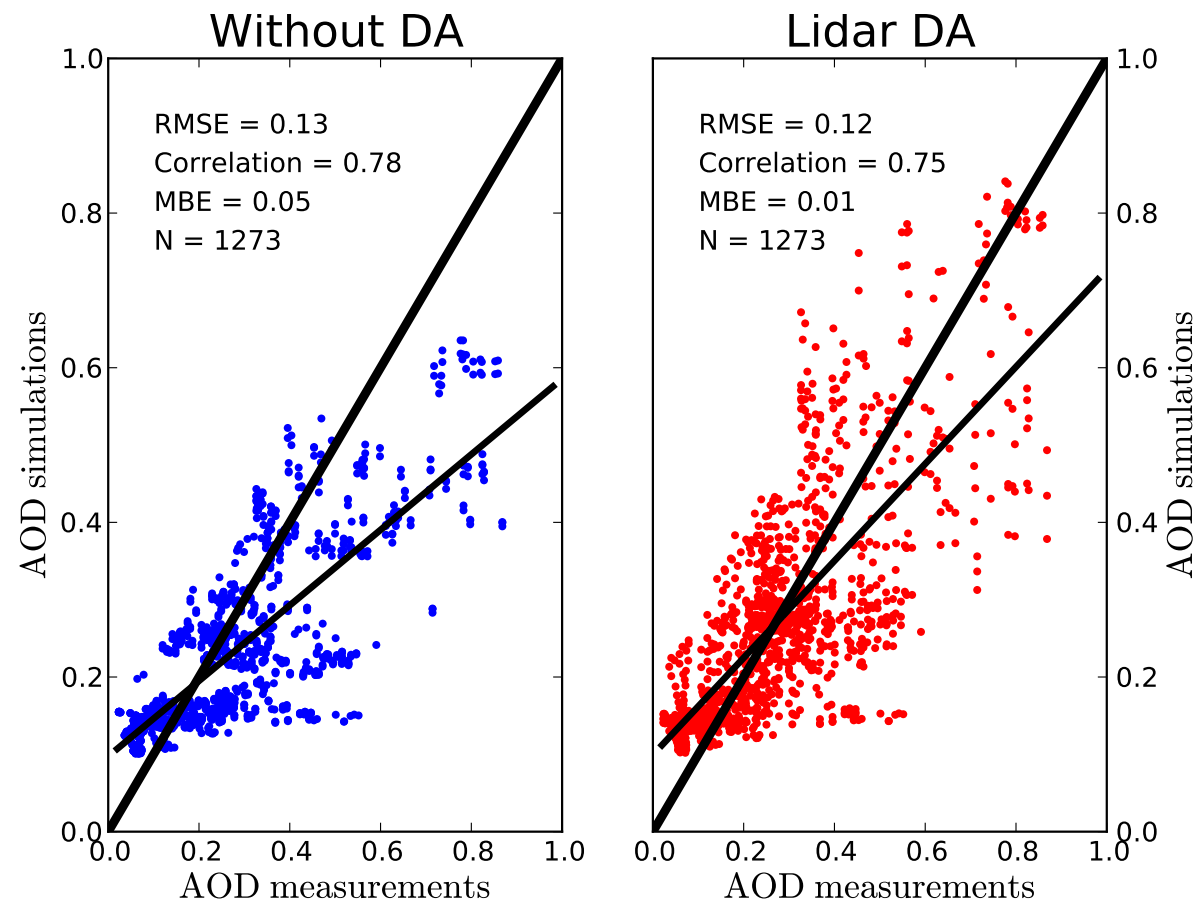

Figure 14. Scatter plots of simulated AODs without DA (left panel) and with DA (right panel) against AOD hourly measurements at different AERONET stations over the first $36 \mathrm{~h}$ of forecast.

\section{Conclusions}

In this paper, a data assimilation (DA) algorithm based on the optimal interpolation (OI) method is used to assimilate lidar signals (normalised $\mathrm{PR}^{2}$ ) for aerosol forecasts over Europe. The lidar data were retrieved from a $72 \mathrm{~h}$ period of intensive and continuous measurements in July 2012. The measurements were performed by 12 ground-based lidar stations of ACTRIS/EARLINET in the Mediterranean basin and one station in Corsica which was set up in the framework of the pre-ChArMEx/TRAQA campaign.

First, we studied the impact of the length of the lidar DA period on aerosol forecasts. We found that $24 \mathrm{~h}$ DA leads to slightly better forecasts than $12 \mathrm{~h}$ DA. However, the differences between $24 \mathrm{~h}$ DA and $12 \mathrm{~h}$ DA are small after $6 \mathrm{~h}$ of forecast. Furthermore, because the impact of lidar DA lasts longer than $36 \mathrm{~h}$ in the forecast period, we have used $12 \mathrm{~h}$ as the assimilation period length in this paper. Also, we conducted sensitivity studies on algorithmic parameters, e.g. the horizontal error correlation length and altitudes at which DA is performed. DA with the error correlation length $L_{\mathrm{h}}=100 \mathrm{~km}$ and assimilation from 1.0 to $3.5 \mathrm{~km}$ a.g.l. leads to the best scores for $\mathrm{PM}_{10}$ and $\mathrm{PM}_{2.5}$ during the forecast period (the evaluation was done using measurements from the BDQA network, since the BDQA network provides the most measurements for the DA validation).

The simulation results without and with lidar DA were evaluated using hourly concentration measurements from the BDQA network over France, daily concentration measure- ments from the EMEP-Spain/Portugal network and AOD measurements from the AERONET network over Europe. The results showed that the simulation with DA leads to better scores than the one without DA for aerosol forecasts $\left(\mathrm{PM}_{2.5}, \mathrm{PM}_{10}\right.$ and $\left.\mathrm{AOD}\right)$. Moreover, the temporal impact of assimilating lidar signals is longer than $36 \mathrm{~h}$, whereas this temporal impact was estimated to be shorter in previous studies that assimilated surface mass concentrations, e.g. between 6 and $12 \mathrm{~h}$, by Tombette et al. (2009) and Jiang et al. (2013). When the temporal impact was estimated using only the three stations around the Barcelona lidar site, the impact lasted longer than $48 \mathrm{~h}$. Additionally, since the model simulates fine particles better than coarse particles, we set a higher error in the background error covariance matrix (see Sects. 2 and 5) for coarse particles than for fine particles, leading to larger corrections by DA of coarse particle concentrations than of fine particle concentrations.

The maximum likelihood ensemble filter (MLEF) (Zupanski, 2005) or the iterative ensemble Kalman filter (IEnKF) (Bocquet and Sakov, 2013a, 2014) could be used in forecasts of aerosols in place of the OI method in order to avoid the tangent linear approximation of the lidar observation operator, and would handle the nonlinearity of the lidar observation operator. They would also update and propagate the background error covariance matrix during the assimilation period. As some lidars provide measurements at several channels, we expect to have better results by assimilating a more extended lidar data set, i.e. $\mathrm{PR}^{2}$, at several channels. 
The lidar-derived PBL height (Morille et al., 2007; Baars et al., 2008; Granados-Muñoz et al., 2012; Lesouëf et al., 2013) could also be assimilated in the model. More accurate PBL heights would improve the forecast ability of air quality models (Pielke and Uliasz, 1998), because the PBL height determines the volume in which pollutants are mixed. Finally, as Schwartz et al. (2012) have shown, simultaneous DA of different aerosol observations ( $\mathrm{PM}_{2.5}$ and $\left.\mathrm{AOD}\right)$ produced the best overall forecasts; for future works, we may combine DA of lidar signals and mass concentration measurements for real-time forecasts of aerosols. 


\section{Appendix A: Statistical indicators}

$\left\{o_{i}\right\}_{i=1, n}$ and $\left\{s_{i}\right\}_{i=1, n}$ are the observed and modelled aerosol concentrations at time $i$, respectively. $n$ is the number of available observations. The statistical indicators used to evaluate the results with respect to observations are the root mean square error (RMSE), the (Pearson) correlation, the mean fractional error (MFE), the mean fractional bias (MFB) and the mean bias error (MBE). The statistical indicators are defined as follows:

$\mathrm{RMSE}=\sqrt{\frac{1}{n} \sum_{i=1}^{n}\left(o_{i}-s_{i}\right)^{2}}$,

correlation $=\frac{\sum_{i=1}^{n}\left(o_{i}-\bar{o}\right)\left(s_{i}-\bar{s}\right)}{\sqrt{\sum_{i=1}^{n}\left(o_{i}-\bar{o}\right)^{2} \sum_{i=1}^{n}\left(s_{i}-\bar{s}\right)^{2}}}$,

$\mathrm{MFE}=\frac{1}{n} \sum_{i=1}^{n} \frac{\left|s_{i}-o_{i}\right|}{\left(s_{i}+o_{i}\right) / 2}$,

$\mathrm{MFB}=\frac{1}{n} \sum_{i=1}^{n} \frac{s_{i}-o_{i}}{\left(s_{i}+o_{i}\right) / 2}$,

$\mathrm{MBE}=\frac{1}{n} \sum_{i=1}^{n} s_{i}-o_{i}$,

where $\bar{o}=\frac{1}{n} \sum_{i=1}^{n} o_{i}$ and $\bar{s}=\frac{1}{n} \sum_{i=1}^{n} s_{i}$. 
Acknowledgements. This work was supported by CEA (Commissariat à l'Énergie Atomique) and CEREA joint laboratory École des Ponts ParisTech - EDF R\&D. We thank all participants of the EARLINET network and MISTRALS/ChArMEx (ChemistryAerosol Mediterranean Experiment, http://charmex.lsce.ipsl.fr/) for the $72 \mathrm{~h}$ continuous measurements. Forecasts and near-real-time quick looks for the lidar measurement alert have been provided by the MISTRALS/ChArMEx Operating Center (http://choc.sedoo.fr/) set-up at OMP (L'Observatoire Midi-Pyrénées), Toulouse. Lidar measurements are supported by the 7th Framework Programme project Aerosols, Clouds, and Trace Gases Research InfraStructure (ACTRIS) network (grant agreement no. 262254). The Barcelona EARLINET lidar team thanks the Spanish Ministry of Economy and Competitivity and European Regional Development (FEDER) funds through project TEC2012-34575 and Scientific and Technological Infrastructure project UNPC10-4E-442, as well as the Spanish Ministry of Science and Innovation and FEDER funds under projects CGL2011-13580-E/CLI and CGL2011-16124-E/CLI.

Edited by: O. Dubovik

\section{References}

Adhikary, B., Kulkarni, S., Dallura, A., Tang, Y., Chai, T., Leung, L. R., Qian, Y., Chung, C. E., Ramanathan, V., and Carmichael, G. R.: A regional scale chemical transport modeling of Asian aerosols with data assimilation of AOD observations using optimal interpolation technique, Atmos. Environ., 42, 8600-8615, 2008.

Ansmann, A., Wandinger, U., Riebesell, M., Weitkamp, C., and Michaelis, W.: Independent measurement of extinction and backscatter profiles in cirrus clouds by using a combined Raman elastic-backscatter lidar, Appl. Optics, 31, 7113-7131, doi:10.1364/AO.31.007113, 1992.

Austin, J.: Toward the four dimensional assimilation of stratospheric chemical constituents, J. Geophys. Res., 97, 2569-2588, doi:10.1029/91JD02603, 1992.

Baars, H., Ansmann, A., Engelmann, R., and Althausen, D.: Continuous monitoring of the boundary-layer top with lidar, Atmos. Chem. Phys., 8, 7281-7296, doi:10.5194/acp-8-7281-2008, 2008.

Balgovind, R., Dalcher, A., Ghil, M., and Kalnay, E.: A stochasticdynamic model for the spatial structure of forecast error statistics, Mon. Weather Rev., 111, 701-722, 1983.

Benedetti, A. and Fisher, M.: Background error statistics for aerosols, Q. J. Roy. Meteor. Soc., 133, 391-405, 2007.

Benedetti, A., Morcrette, J., Boucher, O., Dethof, A., Engelen, R. J., Fisher, M., Flentje, H., Huneeus, N., Jones, L., Kaiser, J. W., Kinne, S., Mangold, A., Razinger, M., Simmons, A. J., and Suttie, M.: Aerosol analysis and forecast in the European Centre for Medium-Range Weather Forecasts Integrated Forecast System: 2. Data assimilation, J. Geophys. Res., 114, 1-18, 2009.

Bocquet, M. and Sakov, P.: Joint state and parameter estimation with an iterative ensemble Kalman smoother, Nonlin. Processes Geophys., 20, 803-818, doi:10.5194/npg-20-803-2013, 2013a.

Bocquet, M. and Sakov, P.: An iterative ensemble Kalman smoother, Quarterly Journal of the Royal Meteorological Society, 140, 1521-1535, doi:10.1002/qj.2236, 2014.
Bösenberg, J., Matthias, V., Amodeo, A., Amoiridis, V., Ansmann, A., Baldasano, J. M., Balin, I., Balis, D., Böckmann, C., Boselli, A., Carlsson, G., Chaikovsky, A., Chourdakis, G., Comeron, A., De Tomasi, F., Eixmann, R., Freudenthaler, V., Giehl, H., Grigorov, I., Hagard, A., Iarlori, M., Kirsche, A., Kolarov, G., Kolarev, L., Komguem, G., Kreipl, S., Kumpf, W., Larchevêque, G., Linné, H., Matthey, R., Mattis, I., Mekler, A., Mironova, I., Mitev, V., Mona, L., Müller, D., Music, S., Nickovic, S., Pandolfi, M., Papayannis, A., Pappalardo, G., Pelon, J., Pérez, C., Perrone, R. M., Persson, R., Resendes, D. P., Rizi, V., Rocadenbosch, F., Rodrigues, J. A., Sauvage, L., Schneidenbach, L., Schumacher, R., Shcherbakov, V., Simeonov, V., Sobolewski, P., Spinelli, N., Stachlewska, I., Stoyanov, D., Trickl, T., Tsaknakis, G., Vaughan, G., Wandinger, U., Wang, X., Wiegner, M., Zavrtanik, M., and Zerefos, C.: EARLINET: a European Aerosol Research Lidar Network to Establish an Aerosol Climatology, Tech. Rep. 348, Max-Planck-Institut für Meteorologie, Hamburg, Germany, 2003.

Boylan, J. W. and Russell, A. G.: PM and light extinction model performance metrics, goals, and criteria for three-dimensional air quality models, Atmos. Environ., 40, 4946-4959, 2006.

Campbell, J. R., Reid, J. S., Westphal, D. L., Zhang, J., Hyer, E. J., and Welton, E. J.: CALIOP aerosol subset processing for global aerosol transport model data assimilation, Journal of Selected Topics in Applied Earth Observations and Remote Sensing, 203214, doi:10.1109/JSTARS.2010.2044868, 2010.

Candiani, G., Carnevale, C., Finzi, G., Pisoni, E., and Volta, M.: A comparison of reanalysis techniques: applying optimal interpolation and Ensemble Kalman Filtering to improve air quality monitoring at mesoscale, Sci. Total Environ., 458, 7-14, doi:10.1016/j.scitotenv.2013.03.089, 2013.

Chazette, P., Randriamiarisoa, H., Sanak, J., Couvert, P., and Flamant, C.: Optical properties of urban aerosol from airborne and ground-based in situ measurements performed during the Etude et Simulation de la Qualité de l'air en Ile de France (ESQUIF) program, J. Geophys. Res., 110, 1-20, doi:10.1029/2004JD004810, 2005.

Collins, W. D., Rasch, P. J., Eaton, B. E., Khattatov, B. V., Lamarque, J.-F., and Zender, C. S.: Simulating aerosols using a chemical transport model with assimilation of satellite aerosol retrievals: methodology for INDOEX, J. Geophys. Res., 106, 7313-7336, doi:10.1029/2000JD900507, 2001.

Daley, R.: Atmospheric Data Analysis, Cambridge University Press, Cambridge, 1991.

D’Amico, G., Binietoglou, I., Amodeo, A., Pappalardo, G., Baars, H., Engelmann, R., Freudenthaler, V., Nicolae, D., Chaikovsky, A., Apituley, A., and Adam, M.: EARLINET single calculus chain for automatic lidar data processing: first tests on optical products, in: 26th International Laser Radar Conference, 25/06/2012-29/06/2012, edited by: Papayannis, A., Balis, D., and Amiridis, V., Porto Heli, Greece, 331-334, 2012.

Dawson, J. P., Adams, P. J., and Pandis, S. N.: Sensitivity of $\mathrm{PM}_{2.5}$ to climate in the Eastern US: a modeling case study, Atmospheric Chemistry and Physics, 7, 4295-4309, doi:10.5194/acp-7-42952007, 2007.

de Meij, A., Krol, M., Dentener, F., Vignati, E., Cuvelier, C., and Thunis, P.: The sensitivity of aerosol in Europe to two different emission inventories and temporal distribution of emis- 
sions, Atmospheric Chemistry and Physics, 6, 4287-4309, doi:10.5194/acp-6-4287-2006, 2006.

Debry, E., Fahey, K., Sartelet, K., Sportisse, B., and Tombette, M.: Technical Note: A new SIze REsolved Aerosol Model (SIREAM), Atmos. Chem. Phys., 7, 1537-1547, doi:10.5194/acp-7-1537-2007, 2007.

Denby, B., Schaap, M., Segers, A., Builtjes, P., and Hora, J.: Comparison of two data assimilation methods for assessing $\mathrm{PM}_{10}$ exceedances on the European scale, Atmos. Environ., 42, 71227134, doi:10.1016/j.atmosenv.2008.05.058, 2008.

Dockery, D. and Pope, A.: Epidemiology of acute health effects: summary of time-series, in: Particles in Our Air: Concentration and Health Effects, Harvard University Press, 123-147, 1996.

Draxler, R. R. and Rolph, G. D.: HYSPLIT (HYbrid Single-Particle Lagrangian Integrated Trajectory) Model access via NOAA ARL READY Website, available at: http://ready.arl.noaa.gov/ HYSPLIT.php (last access: 19 May 2014), NOAA Air Resources Laboratory, Silver Spring, MD, 2014.

Elbern, H. and Schmidt, H.: A four-dimensional variational chemistry data assimilation scheme for Eulerian chemistry transport modeling, J. Geophys. Res., 104, 18583-18598, 1999.

Emmons, L. K., Walters, S., Hess, P. G., Lamarque, J.-F., Pfister, G. G., Fillmore, D., Granier, C., Guenther, A., Kinnison, D., Laepple, T., Orlando, J., Tie, X., Tyndall, G., Wiedinmyer, C., Baughcum, S. L., and Kloster, S.: Description and evaluation of the Model for Ozone and Related chemical Tracers, version 4 (MOZART-4), Geosci. Model Dev., 3, 43-67, doi:10.5194/gmd3-43-2010, 2010.

Evensen, G.: Data Assimilation: the Ensemble Kalman Filter, Springer, Berlin, Germany, 2009.

Fisher, M. and Lary, D. J.: Lagrangian four-dimensional variational data assimilation of chemical species, J. Geophys. Res., 121, 1681-1704, doi:10.1002/qj.49712152709, 1995.

Granados-Muñoz, M. J., Navas-Guzmán, F., Bravo-Aranda, J. A., Guerrero-Rascado, J. L., Lyamani, H., Fernández-Gálvez, J., and Alados-Arboledas, L.: Automatic determination of the planetary boundary layer height using lidar: one-year analysis over southeastern Spain, J. Geophys. Res.-Atmos., 117, D18208, doi:10.1029/2012JD017524, 2012.

Hamonou, E., Chazette, P., Balis, D., Dulac, F., Schneider, X., Galani, E., Ancellet, G., and Papayannis, A.: Characterization of the vertical structure of Saharan dust export to the Mediterranean Basin, J. Geophys. Res.-Atmos., 104, 22257-22270, doi:10.1029/1999JD900257, 1999.

Hodzic, A., Vautard, R., Chazette, P., Menut, L., and Bessagnet, B.: Aerosol chemical and optical properties over the Paris area within ESQUIF project, Atmos. Chem. Phys., 6, 3257-3280, doi:10.5194/acp-6-3257-2006, 2006.

Huneeus, N. and Boucher, O.: One-dimensional variational retrieval of aerosol extinction coefficient from synthetic LIDAR and radiometric measurements, J. Geophys. Res., 112, 1-14, doi:10.1029/2006JD007625, 2007.

Huneeus, N., Chevallier, F., and Boucher, O.: Estimating aerosol emissions by assimilating observed aerosol optical depth in a global aerosol model, Atmos. Chem. Phys., 12, 4585-4606, doi:10.5194/acp-12-4585-2012, 2012.

Intergovernment Panel on Climate Control (IPCC): The Physical Science Basis. Contribution of Working Group I to the Fifth Assessment Report of the Intergovernmental Panel on Climate
Change, Tech. rep., Cambridge Univ. Press, Cambridge, UK and New York, NY, USA, 2013.

Jiang, Z., Liu, Z., Wang, T., Schwartz, C. S., Lin, H.-C., and Jiang, F.: Probing into the impact of 3DVAR assimilation of surface $\mathrm{PM}_{10}$ observations over China using process analysis, J. Geophys. Res.-Atmos., 118, 6738-6749, doi:10.1002/jgrd.50495, 2013.

Kahnert, M.: On the observability of chemical and physical aerosol properties by optical observations: inverse modelling with variational data assimilation, Tellus B, 61, 747-755, doi:10.1111/j.1600-0889.2009.00436.x, 2009.

Kalnay, E.: Atmospheric Modeling, Data Assimilation, and Predictability, Cambridge University Press, Cambridge, 2003.

Kim, Y., Couvidat, F., Sartelet, K., and Seigneur, C.: Comparison of different gas-phase mechanisms and aerosol modules for simulating particulate matter formation, J. Air Waste Manage., 61, 1218-1226, doi:10.1080/10473289.2011.603999, 2011.

Klett, J. D.: Lidar inversion with variable backscatter/extinction ratios, Appl. Optics, 24, 1638-1643, 1985.

Lahoz, W., Khattatov, B., and Ménard, R. E.: Data Assimilation Making Sense of Observations, Springer, Berlin, Germany, 2010.

Lauwerys, R., Haufroid, V., Hoet, P., and Lison, D.: Toxicologie industrielle et intoxications professionnelles, Elsevier-Masson, Issy-les-Moulineaux, France, 2007.

Le Dimet, F.-X. and Talagrand, O.: Variational algorithms for analysis and assimilation of meteorological observations: theoretical aspects, Tellus A, 38, 97-110, 1986.

Lesouëf, D., Gheusi, F., Chazette, P., Delmas, R., and Sanak, J.: Low tropospheric layers over Reunion Island in lidar-derived observations and a high-resolution model, Bound.-Lay. Meteorol., 149, 1573-1472, doi:10.1007/s10546-013-9851-9, 2013.

Li, Z., Zang, Z., Li, Q. B., Chao, Y., Chen, D., Ye, Z., Liu, Y., and Liou, K. N.: A three-dimensional variational data assimilation system for multiple aerosol species with WRF/Chem and an application to $\mathrm{PM}_{2.5}$ prediction, Atmos. Chem. Phys., 13, 42654278, doi:10.5194/acp-13-4265-2013, 2013.

Lin, C., Wang, Z., and Zhu, J.: An Ensemble Kalman Filter for severe dust storm data assimilation over China, Atmos. Chem. Phys., 8, 2975-2983, doi:10.5194/acp-8-2975-2008, 2008.

Liu, Z., Liu, Q., Lin, H.-C., Schwartz, C. S., Lee, Y.-H., and Wang, T.: Three-dimensional variational assimilation of MODIS aerosol optical depth: implementation and application to a dust storm over East Asia, J. Geophys. Res., 116, 1-19, doi:10.1029/2011JD016159, 2011.

Lorenc, A.: Analysis methods for numerical weather prediction, Q. J. Roy. Meteor. Soc., 112, 1177-1194, 1986.

Mallet, V., Quélo, D., Sportisse, B., Ahmed de Biasi, M., Debry, É., Korsakissok, I., Wu, L., Roustan, Y., Sartelet, K., Tombette, M., and Foudhil, H.: Technical Note: The air quality modeling system Polyphemus, Atmos. Chem. Phys., 7, 54795487, doi:10.5194/acp-7-5479-2007, 2007.

Ménard, R., Cohn, S. E., Chang, L.-P., and Lyster, P. M.: Assimilation of stratospheric chemical tracer observations using a Kalman filter, Part I: Formulation, Mon. Weather Rev., 128, 2654-2671, 1999.

Monahan, E. C., Spiel, D. E., and Davidson, K. L.: A model of marine aerosol generation via whitecaps and wave disruption, in: Oceanic Whitecaps, edited by: Monahan, E. C. and Nio- 
caill, G. M., Springer Netherlands, the Netherlands, 167-174, 1986.

Morille, Y., Haeffelin, M., Drobinski, P., and Pelon, J.: STRAT: an automated algorithm to retrieve the vertical structure of the atmosphere from single-channel lidar data, J. Atmos. Ocean. Tech., 24, 761-775, doi:10.1175/JTECH2008.1, 2007.

Moulin, C., Lambert, C. E., Dayan, U., Masson, V., Ramonet, M., Bousquet, P., Legrand, M., Balkanski, Y. J., Guelle, W., Marticorena, B., Bergametti, G., and Dulac, F.: Satellite climatology of African dust transport in the Mediterranean atmosphere, J. Geophys. Res.-Atmos., 103, 13137-13144, doi:10.1029/98JD00171, 1998.

Nabat, P., Somot, S., Mallet, M., Chiapello, I., Morcrette, J. J., Solmon, F., Szopa, S., Dulac, F., Collins, W., Ghan, S., Horowitz, L. W., Lamarque, J. F., Lee, Y. H., Naik, V., Nagashima, T., Shindell, D., and Skeie, R.: A 4-D climatology (1979-2009) of the monthly tropospheric aerosol optical depth distribution over the Mediterranean region from a comparative evaluation and blending of remote sensing and model products, Atmos. Meas. Tech., 6, 1287-1314, doi:10.5194/amt-6-12872013, 2013.

Napelenok, S. L., Cohan, D. S., Hu, Y., and Russell, A. G.: Decoupled direct 3D sensitivity analysis for particulate matter (DDM-3D/PM), Atmos. Environ., 40, 6112-6121, doi:10.1016/j.atmosenv.2006.05.039, 2006.

Nicolas, J.: Caractérisation physico-chimique de l'aérosol troposphérique en Méditerranée: sources et devenir, Ph.D. thesis, Univ. Versailles Saint-Quentin, 2013.

Niu, T., Gong, S. L., Zhu, G. F., Liu, H. L., Hu, X. Q., Zhou, C. H., and Wang, Y. Q.: Data assimilation of dust aerosol observations for the CUACE/dust forecasting system, Atmos. Chem. Phys., 8, 3473-3482, doi:10.5194/acp-8-3473-2008, 2008.

Pagowski, M. and Grell, G. A.: Experiments with the assimilation of fine aerosols using an ensemble Kalman filter, J. Geophys. Res., 117, 1-15, doi:10.1029/2012JD018333, 2012.

Pagowski, M., Grell, G. A., Mckeen, S. A., Peckham, S. E., and Devenyi, D.: Three-dimensional variational data assimilation of ozone and fine particulate matter observations: some results using the Weather Research and Forecasting - Chemistry model and Grid-point Statistical Interpolation, Q. J. Roy. Meteor. Soc., 136, 2013-2024, doi:10.1002/qj.700, 2010.

Pappalardo, G., Amodeo, A., Apituley, A., Comeron, A., Freudenthaler, V., Linné, H., Ansmann, A., Bösenberg, J., D’Amico, G., Mattis, I., Mona, L., Wandinger, U., Amiridis, V., AladosArboledas, L., Nicolae, D., and Wiegner, M.: EARLINET: towards an advanced sustainable European aerosol lidar network, Atmos. Meas. Tech., 7, 2389-2409, doi:10.5194/amt-7-23892014, 2014.

Pielke, R. A. and Uliasz, M.: Use of meteorological models as input to regional and mesoscale air quality models - limitations and strengths, Atmos. Environ., 32, 1455-1466, 1998.

Putaud, J.-P., Dingenen, R. V., Alastuey, A., Bauer, H., Birmili, W., Cyrys, J., Flentje, H., Fuzzi, S., Gehrig, R., Hansson, H., Harrison, R., Herrmann, H., Hitzenberger, R., Hüglin, C., Jones, A., Kasper-Giebl, A., Kiss, G., Kousa, A., Kuhlbusch, T., Löschau, G., Maenhaut, W., Molnar, A., Moreno, T., Pekkanen, J., Perrino, C., Pitz, M., Puxbaum, H., Querol, X., Rodriguez, S., Salma, I., Schwarz, J., Smolik, J., Schneider, J., Spindler, G., ten Brink, H., Tursic, J., Viana, M., Wieden- sohler, A., and Raes, F.: A European aerosol phenomenology - 3: Physical and chemical characteristics of particulate matter from 60 rural, urban, and kerbside sites across Europe, Atmos. Environ., 44, 1308-1320, doi:10.1016/j.atmosenv.2009.12.011, 2010.

Randriamiarisoa, H., Chazette, P., Couvert, P., Sanak, J., and Mégie, G.: Relative humidity impact on aerosol parameters in a Paris suburban area, Atmos. Chem. Phys., 6, 1389-1407, doi:10.5194/acp-6-1389-2006, 2006.

Rolph, G. D.: Real-time Environmental Applications and Display sYstem (READY) Website (http://ready.arl.noaa.gov), NOAA Air Resources Laboratory, Silver Spring, MD, 2014.

Roustan, Y. and Bocquet, M.: Inverse modelling for mercury over Europe, Atmos. Chem. Phys., 6, 3085-3098, doi:10.5194/acp-63085-2006, 2006.

Roustan, Y., Sartelet, K., Tombette, M., Debry, E., and Sportisse, B.: Simulation of aerosols and gas-phase species over Europe with the Polyphemus system, Part II: Model sensitivity analysis for 2001, Atmos. Environ., 44, 4219-4229, 2010.

Sartelet, K. N., Debry, E., Fahey, K. M., Roustan, Y., Tombette, M., and Sportisse, B.: Simulation of aerosols and gas-phase species over Europe with the Polyphemus system, Part I: model-to-data comparison for 2001, Atmos. Environ., 29, 6116-6131, 2007.

Sartelet, K. N., Couvidat, F., Seigneur, C., and Roustan, Y.: Impact of biogenic emissions on air quality over Europe and North America, Atmos. Environ., 53, 131-141, doi:10.1016/j.atmosenv.2011.10.046, 2012.

Schaap, M., Spindler, G., Schulz, M., Acker, K., Maenhaut, W., Berner, A., Wieprecht, W., Streit, N., Müller, K., Brüggemann, E., Chi, X., Putaud, J. P., Hitzenberger, R., Puxbaum, H., Baltensperger, U., and ten Brink, H.: Artefacts in the sampling of nitrate studied in the "INTERCOMP" campaigns of EUROTRAC-AEROSOL, Atmos. Environ., 48, 6487-6496, 2004.

Schutgens, N. A. J., Miyoshi, T., Takemura, T., and Nakajima, T.: Applying an ensemble Kalman filter to the assimilation of AERONET observations in a global aerosol transport model, Atmos. Chem. Phys., 10, 2561-2576, doi:10.5194/acp-10-25612010, 2010a.

Schutgens, N. A. J., Miyoshi, T., Takemura, T., and Nakajima, T.: Sensitivity tests for an ensemble Kalman filter for aerosol assimilation, Atmos. Chem. Phys., 10, 6583-6600, doi:10.5194/acp10-6583-2010, 2010b.

Schwartz, C. S., Liu, Z., Lin, H.-C., and Mckeen, S. A.: Simultaneous three-dimensional variational assimilation of surface fine particulate matter and MODIS aerosol optical depth, J. Geophys. Res., 117, 1-22, doi:10.1029/2011JD017383, 2012.

Sekiyama, T. T., Tanaka, T. Y., Shimizu, A., and Miyoshi, T.: Data assimilation of CALIPSO aerosol observations, Atmos. Chem. Phys., 10, 39-49, doi:10.5194/acp-10-39-2010, 2010.

Simpson, D., Fagerli, H., Jonson, J. E., Tsyro, S., Wind, P., and Tuovinen, J. P.: Transboundary acidification, euthrophication and ground level ozone in Europe, Part I: unified EMEP model description, Technical Report, EMEP, Oslo, Norway, 2003.

Sugimoto, N. and Uno, I.: Observation of Asian dust and airpollution aerosols using a network of ground-based lidars (ADNet): realtime data processing for validation/assimilation of chemical transport models, IOP C. Ser. Earth Environ., 7, 012003, doi:10.1088/1755-1307/7/1/012003, 2009. 
Talagrand, O.: Assimilation of observations, an introduction, J. Meteorol. Soc. Jpn., 75, 191-209, 1997.

Thieuleux, F., Moulin, C., Bréon, F. M., Maignan, F., Poitou, J., and Tanré, D.: Remote sensing of aerosols over the oceans using MSG/SEVIRI imagery, Ann. Geophys., 23, 3561-3568, doi:10.5194/angeo-23-3561-2005, 2005.

Tombette, M., Mallet, V., and Sportisse, B.: PM $_{10}$ data assimilation over Europe with the optimal interpolation method, Atmos. Chem. Phys., 9, 57-70, doi:10.5194/acp-9-57-2009, 2009.

Viskari, T., Asmi, E., Kolmonen, P., Vuollekoski, H., Petäjä, T., and Järvinen, H.: Estimation of aerosol particle number distributions with Kalman Filtering - Part 1: Theory, general aspects and statistical validity, Atmos. Chem. Phys., 12, 11767-11779, doi:10.5194/acp-12-11767-2012, 2012.

Wang, H. and Niu, T.: Sensitivity studies of aerosol data assimilation and direct radiative feedbacks in modeling dust aerosols, Atmos. Environ., 64, 208-218, doi:10.1016/j.atmosenv.2012.09.066, 2013.

Wang, K. C., Dickinson, R. E., and Liang, S. L.: Clear sky visibility has decreased over land globally from 1973 to 2007, Science, 323, 1468-1470, 2009.
Wang, Y., Sartelet, K. N., Bocquet, M., and Chazette, P.: Assimilation of ground versus lidar observations for $\mathrm{PM}_{10}$ forecasting, Atmos. Chem. Phys., 13, 269-283, doi:10.5194/acp-13-2692013, 2013.

Wang, Y., Sartelet, K. N., Bocquet, M., and Chazette, P.: Modelling and assimilation of lidar signals over Greater Paris during the MEGAPOLI summer campaign, Atmos. Chem. Phys., 14, 35113532, doi:10.5194/acp-14-3511-2014, 2014.

Wu, L., Mallet, V., Bocquet, M., and Sportisse, B.: A comparison study of data assimilation algorithms for ozone forecasts, J. Geophys. Res., 113, 1-17, doi:10.1029/2008JD009991, 2008.

Yarwood, G., Rao, S., Yocke, M., and Whitten, G.: Updates to the Carbon Bond Chemical Mechanism: CB05 Final Report to the US EPA, RT-0400675, available at: http://www.camx.com/publ/ pdfs/CB05_Final_Report_120805.pdf (last access: 17 October 2013), 2005.

Zhang, J., Campbell, J. R., Reid, J. S., Westphal, D. L., Baker, N. L., Campbell, W. F., and Hyer, E. J.: Evaluating the impact of assimilating CALIOP-derived aerosol extinction profiles on a global mass transport model, Geophys. Res. Lett., 38, L14801, doi:10.1029/2011GL047737, 2011.

Zupanski, M.: Maximum likelihood ensemble filter: theoretical aspects, Mon. Weather Rev., 133, 1710-1726, doi:10.1175/MWR2946.1, 2005. 